Georgia State University

ScholarWorks @ Georgia State University

3-1-2014

\title{
International Competition for PhDs and Postdoctoral Scholars: What Does (and Does Not) Matter
}

\author{
Paula Stephan \\ Georgia State University, pstephan@gsu.edu \\ Giuseppe Scellato \\ Polytechnic of Turin, giuseppe.scellato@polito.it \\ Chiara Franzoni \\ Politecnico di Milano
}

Follow this and additional works at: https://scholarworks.gsu.edu/uwrg_workingpapers

\section{Recommended Citation}

Stephan, Paula; Scellato, Giuseppe; and Franzoni, Chiara, "International Competition for PhDs and Postdoctoral Scholars: What Does (and Does Not) Matter" (2014). UWRG Working Papers. 83.

https://scholarworks.gsu.edu/uwrg_workingpapers/83

This Article is brought to you for free and open access by the Usery Workplace Research Group at ScholarWorks @ Georgia State University. It has been accepted for inclusion in UWRG Working Papers by an authorized administrator of ScholarWorks @ Georgia State University. For more information, please contact scholarworks@gsu.edu. 


\section{W. J. Usery Workplace Research Group Paper Series}

Working Paper 2014-3-1

March 2014

\section{International Competition for PhDs and Postdoctoral Scholars: What Does (and Does Not) Matter}

Paula Stephan

Georgia State University \& NBER

Giuseppe Scellato

Polytechnic of Turin

Chiara Franzoni

Politecnico di Milano

AndREW Young SchoOl 


\title{
International Competition for PhDs and Postdoctoral Scholars: What Does (and Does Not) Matter
}

\author{
Paula Stephan, Giuseppe Scellato and Chiara Franzoni
}

March 7, 2014

Prepared for the NBER Innovation Policy and the Economy Conference, Washington, DC, April 8, 2014

\begin{abstract}
We explore factors that lead students and postdoctoral scholars who train outside their native country to come to the United States rather than go to a third country for study. We use data collected by the authors in 2011 as part of the GlobSci project of research-active scientists working in 16 countries. Our research suggests that public policy plays an important role in attracting the foreign born to study in a country and that the US is a magnet for foreign students and postdocs precisely because the US has excelled in creating a strong educational and research environment. We further find that students who come to the US score factors that are proxies for the research environment higher than students who go to most other countries for training.
\end{abstract}

The authors acknowledge support from Regione Piemonte for the GlobSci project and from the IPE Program, National Bureau of Economic Research. Stephan acknowledges support from the European Commission (FP7) Project "An Observatorium for Science in Society Based in Social Models - SISOB" Contract no. FP7 266588 and Collegio Carlo Alberto Project "Researcher Mobility and Scientific Performance." We have benefited from comments made by participants at the High Skill Immigration Workshop held October 25, 2012 at the NBER as well as from comments by Bill Amis, Annamaria Conti and Carolin Häussler. We thank Cathee Phillips of the National Postdoc Organization for providing data and Rhita Simorangkir for research assistance. 


\section{International Competition for PhDs and Postdoctoral Scholars: \\ What Does (and Does Not) Matter}

\section{Introduction}

In this chapter we explore factors that lead students and postdoctoral scholars who train outside their native country to come to the United States rather than go to a third country for study. The question is of particular importance given the role that the foreign born play in science, the apparent growing competition outside the United States for foreign students and postdocs, and the limited amount of research that has been done to date--largely because of the absence of data--concerning what leads mobile PhD students and postdoctoral scholars to choose one country over another. We use data collected by the authors in 2011 as part of the GlobSci project (Franzoni, Scellato, \& Stephan, 2012) which cover research-active scientists currently working or training in sixteen core countries. The data are also used to address three other questions: (1) how core countries compare in terms of the percent of scientists and engineers working in country who are foreign and received a PhD and/or postdoc training in country; (2) how countries vary in the proclivity of citizens to study abroad and how this proclivity relates to educational and scientific characteristics of the country; and (3) how country patterns have changed overtime. Throughout the paper, country of origin is defined as the country where the scientist was residing at age 18.

Major findings include wide variation by country in the proclivity of foreign students to come for training as well as the probability that citizens train abroad. We also find that the percent of mobile students and postdoctoral scholars who choose to study in the US has declined in recent years, consistent with the initiatives of other countries to attract foreign talent. Our research suggests that public policy plays an important role in attracting the foreign born to study in a country. Mobile researchers score measures of the quality of the research environment in the country of training as highly important in their decision to study abroad. They also score the availability of financial assistance from the host country as playing an important role in their decision. Respondents also report that career opportunities outside their home country are an extremely important factor (if not the most important factor) in their decision to study abroad. Finally, our research suggests that the US is a magnet for foreign students and postdocs precisely because the US has excelled in creating a strong educational and research environment and providing financial support for study. Moreover, our work suggests that 
students who come to the US appreciate these strengths, scoring factors that are proxies for the research environment and financial assistance higher than mobile students and postdocs who go to most other countries for training.

The plan of the paper is as follows: Section 2 examines the role that foreign-born graduate students and postdoctoral scholars play, section 3 discusses factors that contribute to students studying outside their native country, and section 4 sets out policies that countries can and do pursue to attract foreign students and postdocs. Section 5 briefly summarizes the presence of foreign students and postdocs in the US and elsewhere. The GlobSci data are briefly described in Section 6 and analyzed in Section 7. The paper closes with conclusions and discussion.

\section{The role of foreign-born students and postdoctoral scholars}

Foreign-born students and postdoctoral scholars contribute to the educational system and, more generally, to the country where they are trained, in several ways. As students, they populate graduate programs, contributing to the intellectual life and quality of programs and, particularly at lower-ranked programs, helping to build programs. ${ }^{1}$ They also provide a source of assistance in research. In this regard, foreign-born graduate students are more likely to serve as research assistants than are US citizens, as can be inferred from the fact that 49 percent of temporary residents report that their primary support mechanism while in graduate school was a research assistantship; while only 21 percent of US citizens report that their primary means of support was a research assistantship. ${ }^{2}$

Postdoctoral scholars, by definition, work on research. At some US campuses postdocs are preferred over graduate students, not only because they have more advanced training but also because they can be a "relative bargain" compared to graduate students, for whom tuition must be paid (Stephan, 2012). Moreover, the adhoc nature of the postdoctoral labor market-especially for the foreign born who are educated outside the US-can lead to instances where faculty compensate foreign born postdocs at

\footnotetext{
${ }^{1}$ Bound, Turner and Walsh argue that while the supply of slots at top PhD programs is reasonably inelastic, at lower tier institutions the supply is considerably more elastic. They show that it is precisely these programs that witnessed the largest increase in foreign students (Bound, Turner, \& Walsh, 2009).

${ }^{2}$ (National Science Board, 2012, pp. Table 2-11). Calculated for individuals who received their PhD in 2005.
} 
rates below the (already low) rate prescribed by government agencies such as $\mathrm{NIH}{ }^{3}$ A chemist at a research university, by way of example, recounted at a 2013 meeting how faculty on his campus hired foreign postdocs at less than $\$ 25,000$ per year.

Another way in which foreign students contribute to the country where they train is that they can be a source of revenue (Hawthorne, 2009). Although revenue data for foreign students are difficult to parse at the graduate level, there is some indication that foreign graduate students are seen as a revenue source. In the US, for example, 13 percent of the temporary residents report that their primary source of support while in their PhD program was a fellowship ${ }^{4}$ and master's students often pay full tuition. The revenue incentive has grown in recent years, especially as public research universities, such as the University of California, Berkeley and the University of Michigan, increasingly receive less of their funding from the state. While the revenue incentive is most heavily focused on recruiting foreign undergraduates, there is anecdotal evidence that the revenue model is spreading to graduate programs in science and engineering in the US. ${ }^{5}$

Outside the US, revenue can be a major reason that countries recruit international students. In Australia, for example, education has replaced tourism as the country's number one service export (Verbik \& Lasanowski, 2007), although it is difficult to know the extent to which foreign students contribute to revenue at the doctoral level. Universities in Europe often host foreign students from Asian countries whose tuition is paid in full by programs in the home country. Revenue from foreign students in the UK reportedly grew by 28 percent between 2002-2003 and 2004-2005, going from 1.09 billion pounds to 1.4 billion pounds. ${ }^{6}$

Foreign students and postdocs also contribute to the international collaborative capacity of a country, thereby facilitating joint research projects and knowledge flows. Scellato, Franzoni and Stephan, for example, find the foreign born to have larger international networks than do natives. The network

\footnotetext{
${ }^{3}$ The NIH stipend level for NRSA awards for starting postdocs in 2013 was $\$ 39,264$. See http://www.nhlbi.nih.gov/funding/policies/nrsa.htm.

${ }^{4}$ (National Science Board, 2008, pp. Table 2-11)

${ }^{5}$ At the masters level many foreign students pay the full sticker price in terms of tuition. One reason universities, such as SUNY at Stony Brook, give for ratcheting up their masters level enrollment is to generate tuition revenue. In a recent presentation, administrators at Stony Brook made the case that master's enrollment growth could be a "potential source of revenue." See "Revenue Generation Through Graduate Program Growth Stony Brook University." http://www.cgsnet.org/ckfinder/userfiles/files/am10 MartinTaberDreesRemmler.pdf December 3, 2010; Lawrence B. Martin, Charles Taber, Axel Drees, Mary Messina Remmler.

${ }^{6}$ (Tysome, 2006). See http://www.thes.co.uk/current_edition/story.aspx?story_id=2031765.
} 
effect is particularly strong for those who come with $\mathrm{PhD}$ in hand for a postdoctoral position (Scellato, Franzoni, \& Stephan, 2014). ${ }^{7}$

Foreign students also contribute to the workforce of a country, having a high likelihood of staying in the country where they train. The ten-year stay rate for PhDs in science and engineering in the US was over 60 percent when last measured in 2009 (Finn, 2012, p. 9). Although no comparable data have been collected for postdocs in the US, or for PhD students or postdocs in other countries, the GlobSci survey finds the $\mathrm{PhD}$ as well as the postdoc position to be a major entry point among immigrant scientists working in country. It is exactly for recruitment reasons that many countries now actively pursue policies to attract international students and scholars, whom governments see as a "tried and tested" source of skilled labor (Hawthorne, 2009).

There is some evidence to suggest that foreign-born doctoral educated are more productive than the native born and thus contribute disproportionately to scientific outcomes and indirectly to the economy. Levin and Stephan, for example, show that authors of exceptional contributions are disproportionately distributed among the foreign born and foreign educated in the United States (Levin \& Stephan, 1999). Gaulé and Piacentini investigate the productivity of Chinese chemistry students in US $\mathrm{PhD}$ programs and find them to be more productive and to experience a more rapid surge in productivity over time than non-Chinese PhD students (Gaule \& Piacentini, 2013). Grogger and Hanson find evidence that the foreign born who intend to stay in the US after receiving a PhD in S\&E appear to be more able, suggesting that stayers are positively selected in terms of quality (Grogger \& Hanson, 2013). Franzoni, Scellato and Stephan find, after controlling for selection, that mobile scientists, many of whom moved for PhD study, are more productive, consistent with the concept that mobility enhances productivity by generating efficient matches (Franzoni, Scellato, \& Stephan, 2014).

Finally, foreign-born doctoral students who stay can contribute to a country by addressing shortages in certain labor markets, such as information technology. The extent to which these shortages are "real" in the United States is debatable (Teitelbaum, 2014) and in certain fields there is strong evidence that they do not exist (Stephan, 2012).

\footnotetext{
${ }^{7}$ Network size is a self-reported measure of the number of countries with which the scientist had one or more collaborations in the past two years.
} 
Given the number of positive contributions of the foreign born, and the constant, although not necessarily accurate claims that the US faces a shortage of STEM-trained individuals (New York Times editorial, 2013), it is not surprising that President Obama, as well as Congressional leaders, have called for stapling a green card to diplomas of temporary residents who receive PhD training in science and engineering in the US. Related policies have already been adopted in Australia, Canada and New Zealand.

\section{Factors encouraging students to study outside their country of origin}

Factors that lead students to study outside their native country are often described in terms of "push" or "pull." (Mazzarol \& Soutar, 2002). On the push side, students are more likely to leave their native countries when they are unable to find quality graduate programs in their area of interest and/or they perceive job prospects after receiving a degree to be poor (Van Bouwel \& Veugelers, 2012). ${ }^{8}$ On the "pull" side, students are attracted by desirable properties, such as the prestige and quality of programs outside their native country (Perkins \& Neumayer, 2011); (Beine, Noel, \& Ragot, 2012), the infrastructure and availability of support for research, the opportunity to experience a different life style, and the possibility of long term employment in the country where they study. Doctoral training in the US, for example, places one in a relatively good position to receive an $\mathrm{H}-1 \mathrm{~B}$ visa (Bound, Turner, \& Walsh, 2009), especially for those who find employment in academe and at nonprofits, which are exempt from the $\mathrm{H}-1 \mathrm{~B}$ binding cap. ${ }^{9}$ The possibility of migration is also a factor in attracting foreign scholars to take a postdoctoral position in the US, partly in hopes of eventually becoming a permanent resident with a permanent job (Stephan \& Ma, 2005). This appears to be less of a factor in attracting Europeans to take a postdoctoral position outside of country, whether in the US or in Europe. ${ }^{10}$

The possibility of migration plays an important role in attracting graduate students to other countries, as well as to the US. A 1995 study of foreign students enrolled in Australia found migration to be the primary motivation for studying in Australia for 78 percent of international students from China, 64

\footnotetext{
${ }^{8}$ Conversely, students can be restrained from study abroad by restrictive policies of the home country with regard to study abroad (Bound, Turner, \& Walsh, 2009).

${ }^{9}$ Lowell estimates that nearly one-quarter of H-1B visa recipients were first in the US as students (Lowell, 2000)

${ }^{10}$ In studies of France, Germany, the UK and US, Musselin finds that European postdocs "conceived their foreign experience as a personal strategy and aimed at improving their chances for recruitment in their own country." (Musselin, 2004).
} 
percent from Hong Kong, 48 percent from the Philippines, 46 percent from Fiji/Pacific Islands and 43 percent from Malaysia and Singapore (Hawthorne, 2009). ${ }^{11}$

The availability of financial support, either in the form of a fellowship or an assistantship, also plays a key role in the decision of where a foreign student will train (Aslanbeogio \& Monticinos, 1998). Some countries, such as Switzerland, offer handsome stipends to PhD students coming from abroad. In the US, research assistantships are readily available to foreign born (Stephan, 2012). ${ }^{12}$ Tuition costs as well as costs of living also play a role in the decision of where students study. In this regard, the Nordic countries of Finland, Iceland, Norway and Sweden, which charge no fees for higher education, regardless of nationality, have a distinct advantage (Verbik \& Lasanowski, 2007, p. 31) as do assistantships in the US, which generally come with a tuition waiver. ${ }^{13}$

Other factors that encourage students to study outside their native country are the availability of exchange programs that make it easier to study abroad as well as fellowships that encourage mobility. The ERASMUS program, for example, has greatly facilitated mobility among European students since it was initiated in 1987; the Marie Curie program encourages study at the postdoctoral level outside one's country. ${ }^{14}$

Financial support plays an important role in attracting postdoctoral scholars to study outside their country of nativity as well as in attracting doctoral students. Fellowships, such as those provided by the home country, can encourage students to do postdoctoral work outside their country of nativity. The Swiss National Science Foundation, for example, provides funds for PhD recipients to do postdoctoral training abroad and the Marie Curie program of the EU Commission sponsors postdoc training outside of

\footnotetext{
${ }^{11}$ The data were collected at a time when the waiting period after graduation for students to apply to migrate back to Australia was three years.

${ }^{12}$ Although the stipend associated with a graduate research assistantship in the US is not large relative to the starting salary of individuals with a bachelor's degree, being on the magnitude of $\$ 25,000$ plus tuition (Stephan, 2012), it has a higher relative value to foreign born from developing countries than it has to US students.

${ }^{13}$ Sweden recently introduced tuition fees for students from outside of Europe and is reportedly concerned as to how this will affect its enrollment of international doctoral students (van der Wende, 2013).

${ }^{14}$ The ERASMUS program was established in 1987 and allows European Union students to study or do an internship for a period of three months to an academic year in another European country. Currently more than 4,000 institutions participate in 33 countries. The program guarantees that the period spent abroad is recognized by the home university when the student returns, as long as the student abides by terms previously agreed. Students do not pay extra tuition fees to the host university; they may also apply for an Erasmus grant to help cover the additional expense abroad. http://en.wikipedia.org/wiki/Erasmus Programme, accessed January 21, 2014.
} 
country. ${ }^{15}$ Stipends offered by the host country also play a large role in attracting scholars to take a postdoctoral position in a foreign country, as does the number of positions available (Cantwell \& Taylor, 2013). When the NIH budget doubled in the late 1990s and early 2000s, many faculty recruited foreignborn postdocs to take new postdoc positions in their lab funded from NIH grants (Garrison, Stith, \& Gerbi, 2005). More generally, Cantwell and Taylor find a 1 percent increase in federally supported research and development expenditures in the US to be associated with a .5 percent increase in the employment of foreign postdocs (Cantwell \& Taylor, 2013).

The availability (or unavailability) of fringe benefits can also be a factor in the decision of where to study abroad, especially for postdoctoral study, when students are older. Historically, postdocs in the United States have received few fringe benefits and shared few of the working conditions enjoyed by faculty or staff. Over time, and partly in response to pressure from the National Postdoctoral Association (NPA), founded in 2003 , the presence and availability of fringe benefits has grown and working conditions have improved. A survey of programs in the fall of 2011 conducted by the NPA found that 79 percent of the responding institutions provided health insurance to postdocs; 76 percent provided insurance to the postdoc's family. ${ }^{16}$ In terms of family leave, 39 percent of the institutions offered paid maternity leave, 27.6 percent offered paid paternity leave. The availability of other benefits depended upon whether the postdoc was classified as a university employee. Regardless of status, however, a sizeable proportion received neither paid vacation days, holidays nor sick days (National Postdoctoral Association, 2012). ${ }^{17}$

Fringe benefits and working conditions for postdocs, especially in Europe, generally are more generous than in the United States, although there is no systematic study of postdoc compensation across countries. In Switzerland, for example, a citizen of the EU working as a postdoc is covered by Swiss unemployment insurance after working a minimum of two years. A postdoctoral fellow in Italy has five months of mandatory leave for the birth of a child during which she receives a full salary and can take up to three additional months at no pay. Postdocs in Germany receive a monthly family allowance of

\footnotetext{
${ }^{15}$ Since 2007 the Marie Curie has sponsored postdoc training away from Europe. During the last five years it sponsored 439 scholarships for EU citizens to study in the US (EU Commission Report, 2012).

${ }^{16}$ Almost all of the responding institutions were members of the NPA and were thus predisposed to take better care of their postdocs than nonmembers.

${ }^{17}$ With regard to paid vacations, 27 percent of postdocs who were classified as employees received none; 44 percent of those who were not classified as employees received none. In terms of holidays, 14.8 percent of postdoc employees received no paid holidays, 35 percent of the postdocs who were non-employees received no paid holidays. In terms of sick leave, 24 percent of employees received no paid sick leave, 43 percent of postdocs who were not employees received no paid sick days.
} 
150 euros if married and 154 euros per month for each of the first two children; for the third and subsequent children the family allowance increases substantially.

\section{Policies countries pursue to attract foreign students and postdoctoral scholars}

Countries have several arrows in their quiver to encourage foreign students and postdoctoral scholars to come for study. Some of these have been alluded to in the above. Included in the list are:

- Policies related to ease of entry for study (Hawthorne, 2009); (Alden, 2008). In this regard, EU countries, which are borderless for member citizens, have a distinct advantage in attracting students from other EU countries for study. US visa policy implemented initially after 9/11, on the other hand, made it substantially more difficult for students, especially from certain countries, to obtain a visa for study in the United States (Alden, 2008); (Hawthorne, 2009); (Freeman, 2010).

- Migration policies, with the promise of permanent residency. In light of this, some countries have altered their migration policies to make it easier and more certain that one can transition from a student status to a permanent resident or citizen after graduation (Hawthorne, 2009). Australia, since 2007 , has given "near automatic entitlement" to an 18-month visa valid for work experience or further training (Verbik \& Lasanowski, 2007) and, along with Canada, has adopted a point system that makes it significantly easier for foreigners who train in country to become permanent residents. New Zealand has also adopted migration policies that make it significantly easier for foreign students trained in country to stay (Hawthorne, 2009). France, in 2006, adopted a law that established a three-year "skills and talents" residence permit directed at those with advanced science and engineering degrees and offers automatic visa extensions for graduate students to seek work and automatic work permits upon employment (Chaloff \& Lemaitre, 2009). The US has been discussing an immigration plan to provide green cards for foreign-born US-educated STEM Ph.Ds.

- Exchange programs sponsored by governments. Examples are the Fulbright program (Kahn \& MacGarvie, 2012) and the Marie Curie program.

- Funding opportunities and tuition policies for graduate study made available to foreign students. The doubling of the NIH budget in the late 1990s and early 2000s greatly increased the demand for graduate students in the biomedical sciences in the United States (BlumeKohout \& Clark, 2013) and consequently increased funding available for foreign students. A 
number of countries have encouraged study of foreign students by maintaining "near-zero" tuition fee policies. Germany and France, for example, charge negligible fees to international students at any enrollment level (Hawthorne, 2009). New Zealand recently began a policy that waived fees for PhD students.

- The language in which graduate courses are taught. The adoption of English as the lingua franca by most scientific fields has led many countries to adopt policies to teach graduate courses in English. Even China is now offering graduate courses in English, partly in an effort to attract foreign students, as is Japan (Hawthorne, 2009).

- Promotion of research excellence. Research excellence plays a critical role in attracting foreign students and postdocs for study. In this respect, the government plays a crucial role, given that the majority of research funds for public institutions come from government sources (Stephan, 2012).

\section{Foreign students and postdocs in the US and elsewhere}

The presence of the foreign born as graduate students and postdocs in the United States is well documented (Bound, Turner, \& Walsh, 2009) (Freeman, 2010) (Stephan, 2010) (Stephan \& Ma, 2005) and thus only briefly summarized here.

The percent of foreign-born students receiving PhD training in the US in the natural sciences and engineering has increased consistently since the late 1970s with but two exceptions (Figure 1). The last dip, which began in the late 2000s and largely reflects visa restrictions put in place after 9/11 (Alden, 2008), had begun to reverse itself by 2010 as a result of changes to these policies in the mid-2000s. In 2011, more than 45 percent of PhD recipients in science and engineering were either temporary or permanent residents, down from a high of slightly over 50 percent in 2006. 
Figure 1 Total S\&E PhDs by Citizenship Status: $1966-2011^{18}$

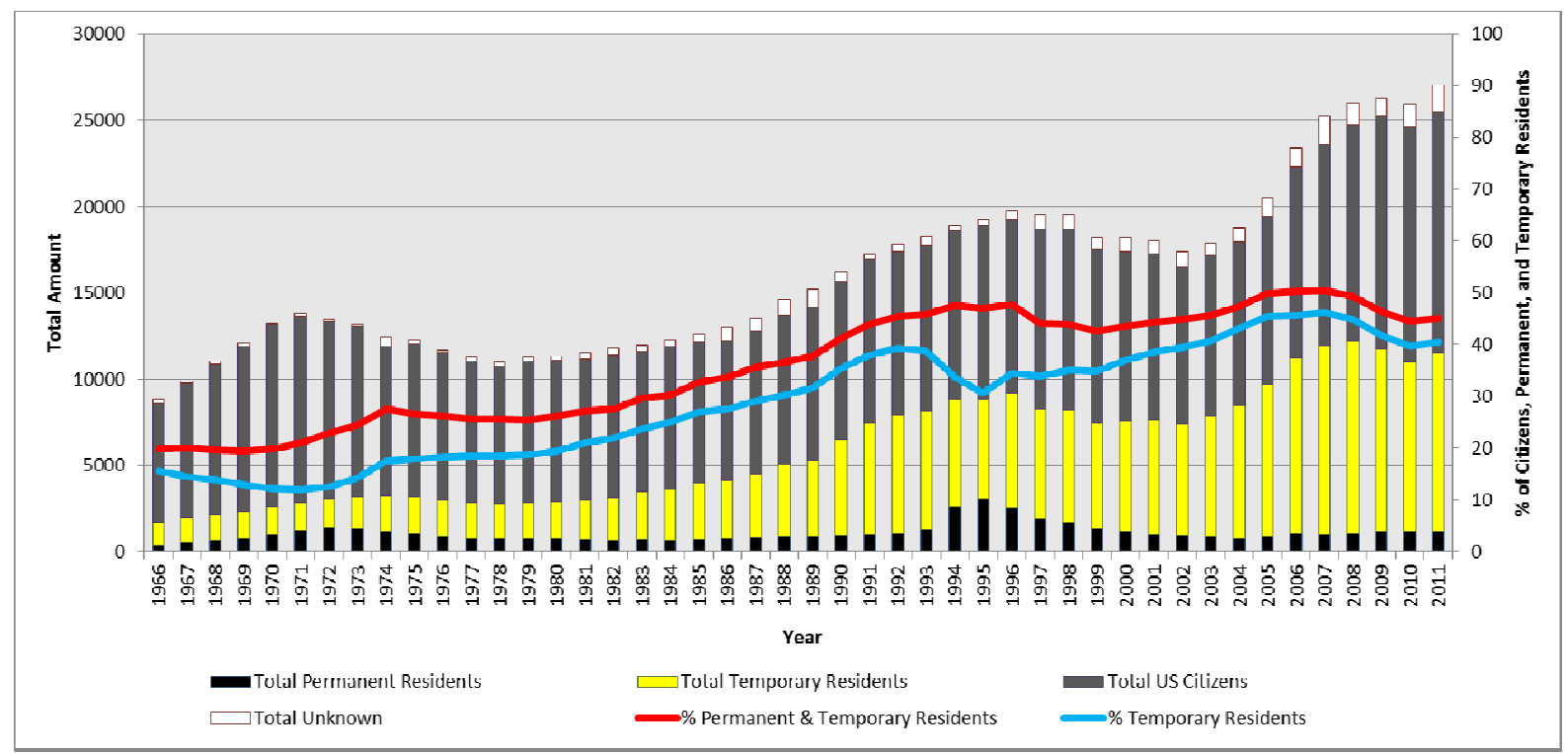

Fields vary considerably in terms of how foreign they are. Engineering has the largest tradition; since the late 1970s, the number of engineering PhD degrees going to foreigners has exceeded the number going to US citizens. The physical sciences are also heavily populated by students from abroad, with slightly over 40 percent of the degrees in the field going to temporary residents. The field least populated by the foreign born is the life sciences, but even in this field in 2012 slightly over a quarter of degrees were awarded to temporary residents. ${ }^{19}$

Almost half of the noncitizens receiving a PhD in the United States currently come from three countries: China, India and South Korea. Their importance is illustrated by the fact that three of the top five undergraduate "feeder" programs for PhD programs in the US are outside the United States: Tsinghua University, Peking University and Seoul National University (Mervis, 2008). ${ }^{20}$

The number of foreign postdoctoral scholars working in the United States grew rapidly between the mid-1980s and early in this century, hitting a high of 61 percent in 2001 (Figure 2). Since 2006 it has been slightly below 60 percent, reflecting the hiring of more citizens and permanent residents as

\footnotetext{
${ }^{18}$ For purposes of consistency over time, the S\&E fields exclude "medical/health sciences" and "other life sciences." Data also exclude PhD recipients in the social sciences and psychology. Data come from the Survey of Earned Doctorates (SED) available at the NSF WebCASPAR web site. https://ncsesdata.nsf.gov/webcaspar/.

${ }^{19}$ Table 17, (National Science Foundation, 2013)

${ }^{20}$ Tsinghua University is first, Peking is second, Seoul National is fourth. Third place belongs to the University of California-Berkeley and fifth place belongs to Cornell University.
} 
postdocs. The increase in permanent residents and citizens likely reflects deteriorating job market conditions for PhDs, especially since 2007, and the availability of ARRA funds in 2009 and 2010 to hire postdocs.

Figure 2: Number of Postdoctorates by Citizenship in Science and Engineering ${ }^{21}$

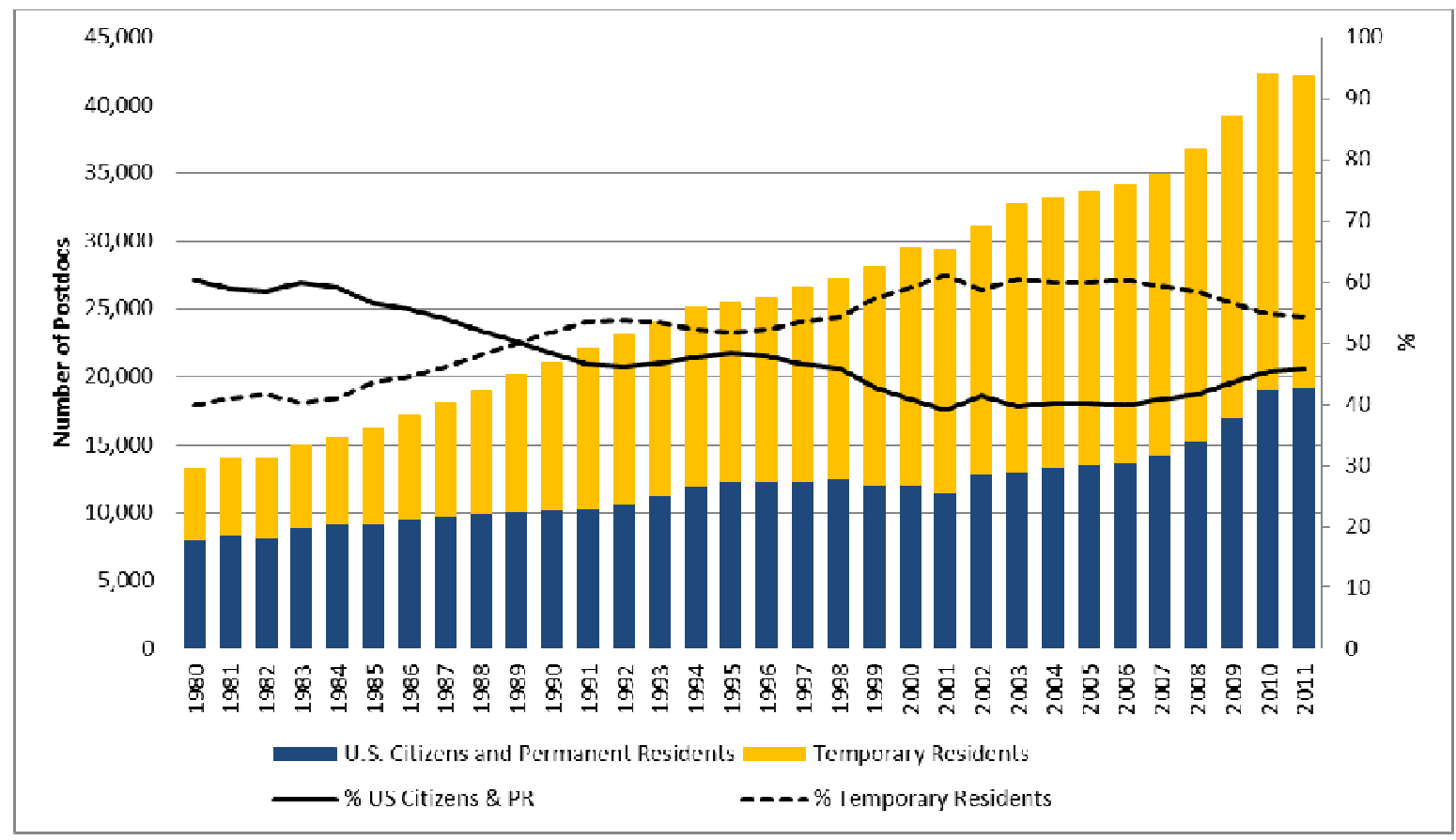

While many foreign postdocs receive their PhD training in the US, a not insignificant number arrive after completion of their PhD. Exact estimates, however, are difficult to make because the primary survey of PhDs working in the United States (SDR) only collects information on those receiving their PhD in the United States. However, at least one researcher estimates that as many as fifty percent of all postdocs working in the US received their PhD outside the US (Regets, 2005).

The vast majority of postdoctoral appointments are in the life sciences, and the largest increase in the absolute number of postdoctoral positions held by temporary residents in recent years has been in the life sciences (Garrison, Stith, \& Gerbi, 2005). In 2008, for example, 56 percent of postdocs working in the life sciences were temporary residents. But the percentage of foreign postdocs is even higher in

\footnotetext{
${ }^{21}$ The figure excludes the social sciences and psychology, as well as the medical sciences, where many of the positions labeled as "postdoctorate" in NSF's Survey of Graduate Students and Postdoctorates in Science and Engineering (GSS) are held by physicians rather than PhDs.
} 
other fields. In engineering, for example, nearly two out of three postdocs are foreign; the proportion is almost the same in the physical sciences.

The US plays a leading role in educating foreign-born doctoral researchers, training more than four times as many foreign doctoral students as the UK, ten times more than Spain, ten times more than Switzerland and Sweden combined, and twelve times more than Australia. Nonetheless, and as these data show, the United States is not the only country that trains the foreign born. In 2004, for example, 22.4 percent of all doctoral candidates in the European Union were training in a country in which they were not a citizen. Three-fourths of these came from non-European Union countries (IISER, 2007). More importantly, in recent years the number of PhD degrees awarded to foreigners has grown considerably in Europe, as well as in Canada, Japan and Australia. For example, in 1999 only 14.8 percent of students enrolled in graduate programs in the natural sciences and engineering in Canada was foreign; by 2008 the number had increased to 25.6 percent (National Science Board, 2012, pp. Table 2-42). ${ }^{22}$ In the United Kingdom the percent of foreign students in graduate programs in the natural sciences and engineering increased from 28.8 percent in 1998-1999 to 51.2 percent in 2008-2009 (National Science Board, 2012, pp. Table 2-40). ${ }^{23}$ Even Japan, which has a reputation for being somewhat insular when it comes to educating foreign students and poses serious language challenges for many, has experienced an increase. In 2004 foreign students represented 8.4 percent of those enrolled in graduate school in the natural sciences and in engineering; in 2010 they represented 10.9 percent (National Science Board, 2012, pp. Table 2-41). ${ }^{24}$

In recent years the postdoctoral position has gained in popularity outside the United States, although data on the actual number of postdoctoral scholars working outside the US is sketchy and even sketchier when it comes to information concerning the proportion who are foreign born or foreign educated. But what we do know suggests that the presence of the foreign born is substantial among the postdoc population. For example, one study found that 43 percent of the 19,000 postdoctoral fellows in the life sciences in Europe are working outside their country of citizenship. Of these, 44 percent are from another European country; 56 percent are from outside the EU (IISER, 2007). 
Despite these facts, because of a lack of consistent data it is difficult if not impossible to compare countries in terms of the proclivity to train foreign born in science and engineering and the proclivity of residents to go abroad for training. OECD data, for example, are generally not available by level of tertiary training, field of training and proportion foreign born, although statistics on the foreign born are available at a more aggregated level, such as for all tertiary students (OECD, 2009). ${ }^{25}$ Moreover, and again because of data limitations, virtually nothing is known about what leads PhD students who go abroad to choose one country over another or what factors lead newly minted PhDs to take a postdoctoral position in one country rather than another. The GlobSci survey allows us to address a number of these issues.

\section{GlobSci survey}

We surveyed 47,304 active researchers in the four scientific disciplines of biology, chemistry, earth and environmental sciences, and materials science working or studying in 16 countries during February-June 2011. Researchers were randomly selected on the basis of being a corresponding author of an article published in 2009 in a journal related to one of the four fields. Countries included are: Australia, Belgium, Brazil, Canada, Denmark, France, Germany, India, Italy, Japan, Netherlands, Spain, Sweden, Switzerland, United Kingdom, United States. In the subsequent sections we refer to this set of countries as "core countries." Collectively, the 16 core countries produce about 70 percent of all articles published in these fields.

Panelists were invited to participate by email. The overall response rate is 40.6 percent. The response rate, conditional on completing the survey, is 35.6 percent. $^{26}$ Response rate bias is discussed in Supporting Information (Franzoni, Scellato, \& Stephan, 2012).The sampling strategy and procedure is discussed in Franzoni, Scellato and Stephan (2012). China was initially included in the survey. However, a low response rate of less than 5 percent for a test sample of Chinese addresses suggested that respondents were either not receiving the invitation or had problems responding to the invitation. We

\footnotetext{
${ }^{26}$ Most web-based surveys have a response rate of 10-25 percent (Sauermann \& Roach, 2013). Our reported response rates do not take into account undelivered invitations due to such things as incorrect email address, retirement or death and consequently underestimate the response rate of those receiving invitations. Undelivered emails generally account for between 3 to 6 percent of a sample in the US (Walsh, Cho, \& Cohen, 2005) and (Sauermann \& Roach, 2010).
} 
encountered somewhat similar problems in a later effort to survey scientists in South Korea. We thus decided not to survey researchers based in China or South Korea.

For purposes of analysis we consider two samples of the foreign born (Table 1). The first includes foreign born who reside in a core country in 2011 and received their PhD in 2000 or later, or, for a small handful, were enrolled in a PhD program in a core country at the time they responded to the questionnaire. We refer to this group as the Recent Cohort sample. Included are all individuals living in a core country in 2011, regardless of country of origin, who studied or are studying for a PhD in a country different from where they lived when they were age 18. The recentness of the sample minimizes censoring effects that arise when foreign born who train in one of the core countries relocate to a country (such as China) that is not included in our survey. The second sample, with no time constraints, is restricted to those who resided in a core country at age 18 and received their PhD in a different country. We refer to this as the Core Country sample. We construct the second sample in this way in order to capture individuals who may have trained abroad but subsequently returned to their home country. The samples are subdivided between those who were mobile for their PhD and those who were mobile for the postdoc.

Table 1 Criteria for inclusion in the sub-samples

\begin{tabular}{|l|l|c|c|c|}
\hline Sample & Criteria for inclusion & Number & $\begin{array}{c}\text { Of which } \\
\text { mobile for } \\
\text { Phd }\end{array}$ & $\begin{array}{c}\text { Of which } \\
\text { mobile for } \\
\text { postdoc }\end{array}$ \\
\hline Recent cohort & Respondents who received their PhD in 2000 or later from all origins. & 5602 & 1165 & 2098 \\
\hline Core country & Respondents who lived at age 18 in a core country (no PhD cohort limitation) & 14125 & 1348 & 5448 \\
\hline
\end{tabular}

\section{Analysis of GlobSci Data}

\subsection{PhD and Postdoctoral study abroad}

Columns 2 and 3 of Table 2 present data regarding the percent who left their country of origin for either $\mathrm{PhD}$ and/or postdoctoral study for the Recent Cohort sample. Columns 4 and 5 give the percent of scientists in the recent cohort living in country who are foreign and received their $\mathrm{PhD}$ and/or postdoctoral training in country. ${ }^{27}$ Columns 6-8 provide data on three characteristics of the educational and research environment of the country: the number of institutions ranked in the top 400 by World

\footnotetext{
${ }^{27}$ By construction, columns 2 and 3 are restricted to residents at age 18 of core countries; columns 3 and 4 include residents at age 18 of any country who in 2011 were working or studying in a core country.
} 
University Rankings; the percent of GDP spent on higher education, research and development (HERD), and the $\mathrm{H}$-Index, a measure of highly cited publications authored in country. ${ }^{28}$ The table is restricted to the Recent Cohort sample because the number of top institutions and the $\mathrm{H}$-Index are only available for recent years.

There are no surprises at the extremes in terms of the percent who go abroad for training: the US has the lowest (2.7 percent), followed closely by Japan with 2.9 percent. India has the highest, with 31.4 percent. What is perhaps surprising is that Switzerland is second highest, with 20.6 percent of natives leaving the country for PhD study, followed neck and neck by Germany and Canada, at 18.7 and 18.6 percent and, more distantly, by Italy at 12.2 percent. Country characteristics are consistent with the very extremes. The US has almost one-fourth of the top 400 institutions and enjoys the highest $\mathrm{H}$-Index. India has the lowest $\mathrm{H}$-index among core countries and only 5 of the top 400 institutions, consistent with "push" factors. However, two of the next countries (Canada and Germany) have a reasonable share of top 400 institutions and an $\mathrm{H}$-index above the median for core countries of $572 .^{29}$

The postdoc patterns are more nuanced. Although again the US has the lowest percent doing a postdoc abroad (8.7 percent), the next lowest belongs to Brazil (15.8 percent), and that of Japan, though third, is more than twice as high as that of the US. Furthermore, while almost one-in-two Indian scientists did postdoctoral training abroad the rate is higher for the French (53.3 percent) and still higher for the Swiss (54.9 percent). The research and educational environment in both countries, as measured by the three characteristics of columns 6-7, are stronger than those in India, suggesting that pull factors in the country of destination may play a greater role than push factors in encouraging postdoctoral study abroad. $^{30}$ The findings are also consistent with Musselin's observation that many Europeans take a postdoc position abroad to enhance their options of being hired at home (Musselin, 2004).

\footnotetext{
${ }^{28}$ The World Rankings are for the period 2007 to 2009; HERD is the average for the years 2000-2010 and the HIndex is for the years 1996-2013.

${ }^{29}$ None of the correlation coefficients between the percent leaving and the three measures are significant at traditional levels.

${ }^{30}$ None of the correlations between the percent taking a postdoc abroad and the three measures of research and educational quality are significant at traditional levels.
} 
Table 2 Country descriptive statistics: Recent cohort

\begin{tabular}{|c|c|c|c|c|c|c|c|}
\hline Country & $\begin{array}{l}\text { Percent }(n) \text { of } \\
\text { residents at } \\
\text { age } 18 \text { who } \\
\text { went abroad } \\
\text { for } \mathrm{PhD}^{+} \\
\text {training }^{+}\end{array}$ & $\begin{array}{l}\text { Percent }(n) \text { of } \\
\text { residents at } \\
\text { age } 18 \text { who } \\
\text { did } \\
\text { postdoctoral } \\
\text { training } \\
\text { abroad }^{+}\end{array}$ & $\begin{array}{l}\text { Percent }(n) \\
\text { studying or } \\
\text { working in } \\
\text { country in } \\
2011 \text { who are } \\
\text { foreign and } \\
\text { received PhD } \\
\text { in core } \\
\text { country }\end{array}$ & $\begin{array}{l}\text { Percent (n) } \\
\text { working in } \\
\text { country in } \\
2011 \text { who are } \\
\text { foreign and } \\
\text { did } \\
\text { postdoctoral } \\
\text { training in } \\
\text { core country }\end{array}$ & $\begin{array}{c}\text { Number top } \\
\text { institutions in } \\
\text { QS5400 } \\
\text { rankings* }\end{array}$ & $\begin{array}{c}\text { HERD as } \\
\text { percent of } \\
\text { GDP } \times 1000 * *\end{array}$ & $\begin{array}{c}\mathrm{H}- \\
\text { Index } * * *\end{array}$ \\
\hline Australia & 8.5 & 34.6 & 19.2 & 23.3 & 21 & 48.7 & 378 \\
\hline Belgium & 7.5 & 24.6 & 7.0 & 8.5 & 7 & 42 & 454 \\
\hline Brazil & 12.8 & 15.8 & 3.6 & 3.2 & 3 & n.a. & 305 \\
\hline Canada & 18.6 & 44.5 & 16.9 & 21.5 & 20 & 65.9 & 658 \\
\hline Denmark & 12.8 & 19.1 & 8.0 & 13.3 & 4 & 65.1 & 427 \\
\hline France & 9.8 & 53.3 & 6.8 & 9.5 & 15 & 42.3 & 681 \\
\hline Germany & 18.7 & 44.4 & 12.8 & 18.5 & 35 & 43.3 & 740 \\
\hline India & 31.4 & 48.4 & 0.0 & 0.0 & 5 & n.a. & 301 \\
\hline Italy & 12.2 & 24 & 0.9 & 1.2 & 7 & 35.5 & 588 \\
\hline Japan & 2.9 & 19.5 & 6.3 & 7.5 & 22 & 43.2 & 635 \\
\hline Netherlands & 7.9 & 39.5 & 17.3 & 19.5 & 12 & 65.9 & 576 \\
\hline Spain & 7.6 & 45.1 & 6.4 & 7.2 & 6 & 32.8 & 476 \\
\hline Sweden & 7.7 & 40 & 18.3 & 17.7 & 8 & 81.5 & 511 \\
\hline Switzerland & 20.6 & 54.9 & 22.8 & 37.7 & 8 & n.a. & 569 \\
\hline UK & 9.4 & 32.1 & 20.4 & 30.3 & 45 & 44.4 & 851 \\
\hline USA & 2.7 & 8.7 & 25.2 & 31.0 & 91 & 36.6 & 1380 \\
\hline
\end{tabular}

Core countries vary considerably in terms of the percent of scientists in country who are foreign born and received their PhD in the host country. ${ }^{31}$ The US has the largest percent, followed closely by Switzerland. $^{32}$ No foreign born reported receiving doctoral training in India and working in India. Italy, with less than 1 percent, is extremely close to India and Brazil is not far behind. At least in terms of the extremes, the data are consistent with "pull" factors playing a large role in the percent of foreign born who come for a PhD and remain in country. The data present a fairly similar picture in terms of the percent working in country who are foreign and did (or are doing) postdoctoral training in country. Switzerland is first; almost 40 percent of recent cohort scientists in country are foreign and have done or

\footnotetext{
${ }^{31}$ Less than 6.5 percent were still enrolled in a PhD program at the time they responded to the questionnaire.

${ }^{32}$ Using the 2006 Survey of Doctorate Recipients (SDR) data, Stephan (2012) finds that 21.8 percent of scientists and engineers trained in the United States and working in the US in 2006 were non-citizens at the time they received their PhD. The SDR sample includes all US PhDs working in 2006, not just those trained in 2000 or later. It also includes fields such as engineering that were not surveyed as part of the GlobSci survey.
} 
are doing a postdoc in Switzerland, followed distantly by the US and the UK. India and Italy retain the dubious distinction of last and next-to-last places. ${ }^{33}$

\subsection{Reasons for studying abroad}

A strength of the GlobSci survey is that it asked mobile researchers to asses on a five point scale the importance each of ten factors played in their decision to study abroad for their PhD, with a score of " 1 " being "totally unimportant," a score of " 3 " being "neither important nor unimportant," and a score of " 5 " being "extremely important." Although responses may suffer from recall bias, there is little reason to believe that biases are country specific, either in terms of country of origin or country of destination. On the other hand, responses undoubtedly relate to preferences and circumstances of the respondents and these may vary across country of origin and/or country of destination.

The ten factors are given in Table 3. Three of the variables reflect policies and the level of resources in the home country that can affect emigration for advanced study: fellowship_origin, home career, and no program. The first is specifically designed to encourage study abroad; the third, reflecting the absence of resources, encourages study abroad by default. The home career variable reflects labor market policies and practices in the home country that place a high value on study outside the country. Three variables reflect policies and resources of the host country that either directly or indirectly encourage emigration for advanced study: prestige, fellowship_host, and career. The third, which is differentiated from career opportunities in the home country, reflects both the labor market for scientists in the host country (as well as other third countries) and visa policies in the host country. Two of the variables involve relationships between either individuals or institutions in the home and host country: exchange program and contact. Finally, two reflect personal situations and preferences and how these align with conditions in the host country. The "lifestyle" available at a Midwest university, for example, may not be highly valued by someone coming from a European urban environment; the lack of a substantial community of one's ethnic peers may discourage migration to certain countries. Family reasons may make it difficult to study abroad because of ties to the home country or because of problems in getting visas for family members. While both factors can be affected by policies of the host country, they are not directly affected by science policy in the host country.

\footnotetext{
${ }^{33}$ The correlation coefficients between the percent in country who are foreign born and received their PhD in country and the QS ranking is .594 ( $p=.015)$; and HERD is $0.3378(p=.259)$ and the H-Index is $0.5717 \quad(p=.021)$. Those between the percent in country who did a postdoc in country and QS ranking is 0.5498 ( $p=.0274)$; and HERD is $0.2343(p=.441)$ and $\mathrm{H}$-Index is $0.5485(p=.028)$.
} 
Table 3 Description of factors in decision to study abroad: Recent cohort

\begin{tabular}{|l|l|c|}
\hline Variable name & Factor & Mean \\
\hline Career & Opportunity to improve my future career prospects & 4.4 \\
\hline Prestige & Prestige/research excellence of the institution & 4.2 \\
\hline Lifestyle & Appeal of the life style or international experience & 3.9 \\
\hline Fellowship_host & Fellowship that I obtained from the host country/institution & 3.6 \\
\hline Home Career & Opportunity to improve my future career prospects in the country where I lived when I was 18 & 3.4 \\
\hline Contact & Contact with somebody (a professor, colleague, friend...) in the host country & 3.2 \\
\hline No program & Few if any good PhD programs in the country where I lived when I was 18 & 2.7 \\
\hline Family & Family or personal reasons & 2.5 \\
\hline Exchange program & Availability of an exchange or joint program between institutions & 2.4 \\
\hline Fellowship_origin & Fellowship that I obtained from the country where I lived when I was 18 & 2.2 \\
\hline
\end{tabular}

There is considerable variation in mean scores across the ten factors. Two which relate to science policy in the host country (prestige and career) have mean scores above "4.0." Two others have mean scores between 3.5 and 4.0: fellowship_host and lifestyle. The first of these relates to active science policies on the part of the host country; the second does not. Four have mean scores below 3.0, indicating that respondents on average score the factors as lying between "totally unimportant" and "neither important nor unimportant." The four are family, exchange_program, fellowship_origin and no_program. The latter three depend in part on policies and resources of the home country.

Column 2 of Table 4 provides mean answers to the "no program" for respondents from the Recent Cohort sample from 28 countries with 16 or more respondents working or training in a core country. Columns 3-5 provide summary data by country for the three educational and research characteristics discussed above. ${ }^{34}$ We find substantial variation across countries in the degree to which students score the "no program available" statement as a factor leading them to go outside their country for training. Students who leave the Netherlands give the lowest mean score (1.63) to the factor with those from Great Britain being a close second. (Recall that a "1" means "totally unimportant.") Those who leave Columbia give the highest mean score to the factor (3.27), with those from India giving it only a slightly lower (3.2) score. Simple correlations between the mean score and country characteristics suggest that push factors are at work. They are, respectively, $-.3196(p=.115) ;-.4363(p=.0374)$ and $=.-4490$ $(p=.0165)$.

\footnotetext{
${ }^{34}$ Answers are weighted by the response rate of the country of origin.
} 
Table $4 \mathrm{PhD}$ program availability in country of origin: Recent cohort

\begin{tabular}{|c|c|c|c|c|}
\hline & No program ${ }^{+}$ & $\begin{array}{l}\text { n. top institutions in } \\
\text { QS400 Ranking }\end{array}$ & HERD as \% GDP & H-Index \\
\hline Argentina & 1.92 & 2 & 14.3 & 222 \\
\hline Australia & 2.02 & 21 & 48.7 & 378 \\
\hline Austria & 2.08 & 4 & 63.3 & 378 \\
\hline Belgium & 1.87 & 7 & 42.0 & 454 \\
\hline Brazil & 2.55 & 3 & n.a. & 305 \\
\hline Canada & 1.91 & 20 & 65.9 & 658 \\
\hline China & 1.78 & 8 & n.a. & 569 \\
\hline Colombia & 3.27 & n.a. & n.a. & 133 \\
\hline Denmark & 2.43 & 4 & 65.1 & 427 \\
\hline France & 2.22 & 15 & 42.3 & 681 \\
\hline Germany & 2.22 & 35 & 43.3 & 740 \\
\hline India & 3.20 & 5 & n.a. & 301 \\
\hline Iran & 2.85 & 1 & n.a. & 135 \\
\hline Italy & 3.20 & 7 & 35.5 & 588 \\
\hline Japan & 3.02 & 22 & 43.2 & 635 \\
\hline Korea & 2.65 & 8 & 30.7 & 333 \\
\hline Mexico & 1.87 & 2 & 12.1 & 232 \\
\hline Netherlands & 1.63 & 12 & 65.9 & 576 \\
\hline Portugal & 2.18 & 1 & 36.5 & 234 \\
\hline Roumania & 3.00 & n.a. & 8.0 & 135 \\
\hline Russia & 2.77 & 2 & 7.0 & 325 \\
\hline Spain & 2.61 & 6 & 32.8 & 476 \\
\hline Sweden & 2.03 & 8 & 81.5 & 635 \\
\hline Switzerland & 1.78 & 8 & n.a. & 511 \\
\hline Taiwan & 2.92 & 5 & 29.6 & 93 \\
\hline Turkey & 3.13 & 1 & 33.6 & 210 \\
\hline UK & 1.71 & 45 & 44.4 & 851 \\
\hline USA & 1.95 & 91 & 36.6 & 1380 \\
\hline
\end{tabular}

n.a.: not available at source

+ weighted by probability of response

Figure 3 compares the mean scores for the Recent Cohort of mobile PhD recipients of those coming to the US vs. those going elsewhere for a PhD. Although some variation exists among the scores given by the two groups, overall the means lie reasonably close together, suggesting that in general the same factors either matter or do not matter to individuals doing doctoral training abroad. Despite this, some significant differences exist. These are designated by an asterisk for those significantly different at the .05 or better level.

Consistent with the large number of highly rated universities in the US, prestige of programs plays a more important role in drawing foreign students to study in the US than drawing them elsewhere, as do career reasons. Financial assistance also plays a more important role, reflecting the wide availability of graduate research assistantships for foreign students in the US. Taken together, these findings suggest that conditions influenced by science policy in the US play a role in attracting students to study here vs. elsewhere. Lifestyle and exchange programs, on the other hand, play a larger role in drawing students to study elsewhere than in the United States. While science policy can affect the latter, it cannot affect 
the former. There is no significant difference in the scores for the two groups for the "contact" reason or the "family" reason and no evidence to suggest that mobile PhD students who receive financial support from their home country are more likely to come to the US than go to a third country. The unavailability of programs in the country where the respondent was living at age 18 plays a larger role in drawing foreign students to the US than elsewhere. The implication is that if one gets "pushed" out of one's home country, one comes to the US vs. going elsewhere.

Figure 3 Importance of factors in decision to do a PhD abroad: Recent cohort

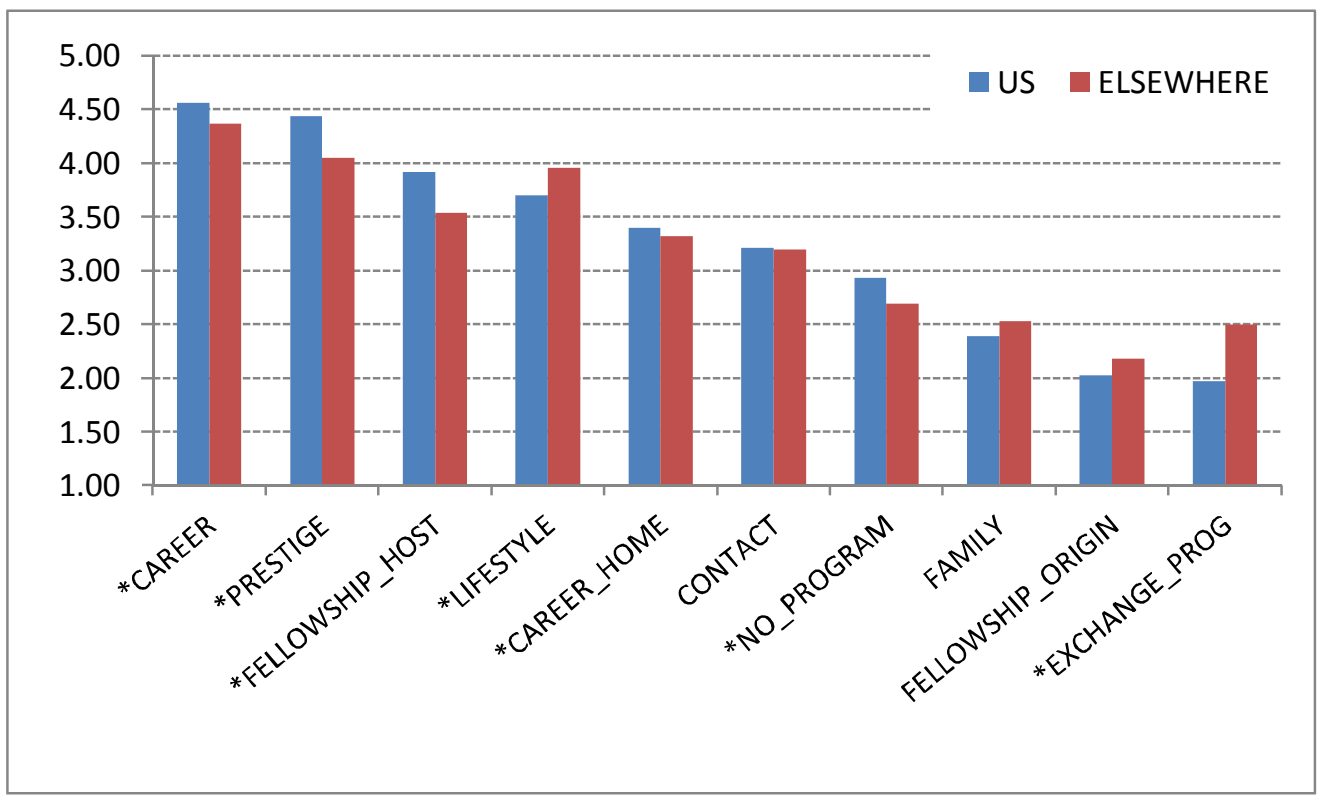

Table 5 compares the mean scores given to the ten factors by individuals coming to the US for study to those given by individuals going to one of six other countries. The one factor that is consistently and significantly scored higher by the US students is prestige of programs. Financial support is scored significantly higher by those coming to the US vs. those going to the UK, France, Switzerland and Germany, but there is no significant difference for those going to Australia or Canada, suggesting that stipends are competitive between these countries and the US. Career factors play a larger role in drawing people to the US vs. those going to most other countries. Again, these findings suggest that science policy, as practiced in the US, plays a role in attracting students to study here. Lifestyle factors are scored significantly lower as a reason for coming to the US than going to the six other countries with the one exception of Australia. The availability of exchange programs leads individuals to study in countries other than the US. 
Table 5 Mean scores, decision to study for PhD abroad: Recent cohort sample. T-test of specific destination vs. US ${ }^{35}$

\begin{tabular}{|c|c|c|c|c|c|c|c|c|c|c|c|c|c|c|c|}
\hline Factors & US & \multicolumn{2}{|c|}{ ELSEWHERE } & \multicolumn{2}{|c|}{ UK } & \multicolumn{2}{|c|}{ FRANCE } & \multicolumn{2}{|c|}{ CANADA } & \multicolumn{2}{|c|}{ AUSTRALIA } & \multicolumn{2}{|c|}{ SWITZERLAND } & \multicolumn{2}{|c|}{ GERMANY } \\
\hline PRESTIGE & 4.44 & 4.05 & $* * *$ & 4.09 & $* * *$ & 4.03 & $* * *$ & 4.20 & $* *$ & 3.74 & $* * *$ & 4.14 & $* * *$ & 4.26 & $* *$ \\
\hline CAREER & 4.56 & 4.37 & $* * *$ & 4.42 & $*$ & 4.39 & $*$ & 4.26 & $* *$ & 4.18 & $* * *$ & 4.40 & & 4.52 & \\
\hline CAREER_HOME & 3.40 & 3.32 & & 3.43 & & 3.43 & & 3.14 & & 3.21 & & 3.14 & & 3.34 & \\
\hline CONTACT & 3.21 & 3.20 & & 2.98 & $*$ & 3.34 & & 3.45 & & 3.43 & & 2.63 & $* * *$ & 3.21 & \\
\hline LIFESTYLE & 3.70 & 3.96 & $* * *$ & 3.96 & $* *$ & 4.08 & $* *$ & 4.16 & $* * *$ & 3.82 & & 4.15 & $* * *$ & 3.94 & $* *$ \\
\hline FAMILY & 2.39 & 2.53 & $*$ & 2.34 & & 2.17 & & 2.83 & $* *$ & 2.83 & $* * *$ & 2.38 & & 2.58 & \\
\hline EXCHANGE_PROG & 1.97 & 2.50 & $* * *$ & 2.24 & $* *$ & 2.93 & $* * *$ & 2.26 & $*$ & 2.33 & $* *$ & 1.85 & & 2.73 & $* * *$ \\
\hline FELLOWSHIP_HOST & 3.92 & 3.54 & $* * *$ & 3.32 & $* * *$ & 3.29 & $* * *$ & 4.06 & & 3.80 & & 3.22 & $* * *$ & 3.52 & $* * *$ \\
\hline FELLOWSHIP_ORIGIN & 2.03 & 2.18 & & 2.29 & $* *$ & 2.45 & $* *$ & 1.99 & & 2.23 & & 1.86 & & 2.05 & \\
\hline NO_PROGRAM & 2.93 & 2.69 & $* * *$ & 2.90 & & 2.54 & $* *$ & 2.36 & $* * *$ & 2.61 & $*$ & 2.60 & $* *$ & 2.90 & \\
\hline
\end{tabular}

Figure 4 compares the mean scores by foreigners who came for study to the US to the mean scores given to the same factors by foreigners who went to another country for study for the Core Country sample. It thus excludes respondents from countries such as China and South Korea, but covers individuals receiving their PhD both before and after the year 2000. The results are similar to those for the Recent PhD sample with the exception that "family" reasons are scored significantly higher by those getting a PhD elsewhere than by those getting a PhD in the US. This may reflect the heavy European composition of the Core Country sample.

Table 6 compares mean scores for the ten factors given by individuals coming to the US for study to the mean scores given by individuals going to the same six other countries for the Core Country sample. The results are consistent with those for the Recent Cohort. Conditions directly related to science policy clearly matter in bringing people to study in the US vs. elsewhere. Prestige is scored significantly higher for those coming to the US than for those going to all other countries except Switzerland, although the level of significance in two cases is at the 10 percent level rather than at the 1 percent level as it was for the Recent sample. Career factors play a larger role in bringing individuals to the US than in bringing them to three of the other countries. Financial assistance from the host country is more important in

$35 * * *=.01$ level of significance; $* *=.05$ level of significance; $* * *=.10$ level of significance 
attracting graduate students to the US than to the UK or France. The availability of exchange programs plays a larger role in bringing students to study in Europe than in the US. This is consistent with the widespread availability of exchange programs in Europe. Great Britain, France and Switzerland hold an edge when it comes to lifestyle. Family factors play a modest but more important role in attracting students to study in most other countries compared to the US. Although these factors are clearly affected by government policy, they are largely outside the scope of active science policy.

Figure 4 Importance of factors in decision to do a PhD abroad: Core country sample

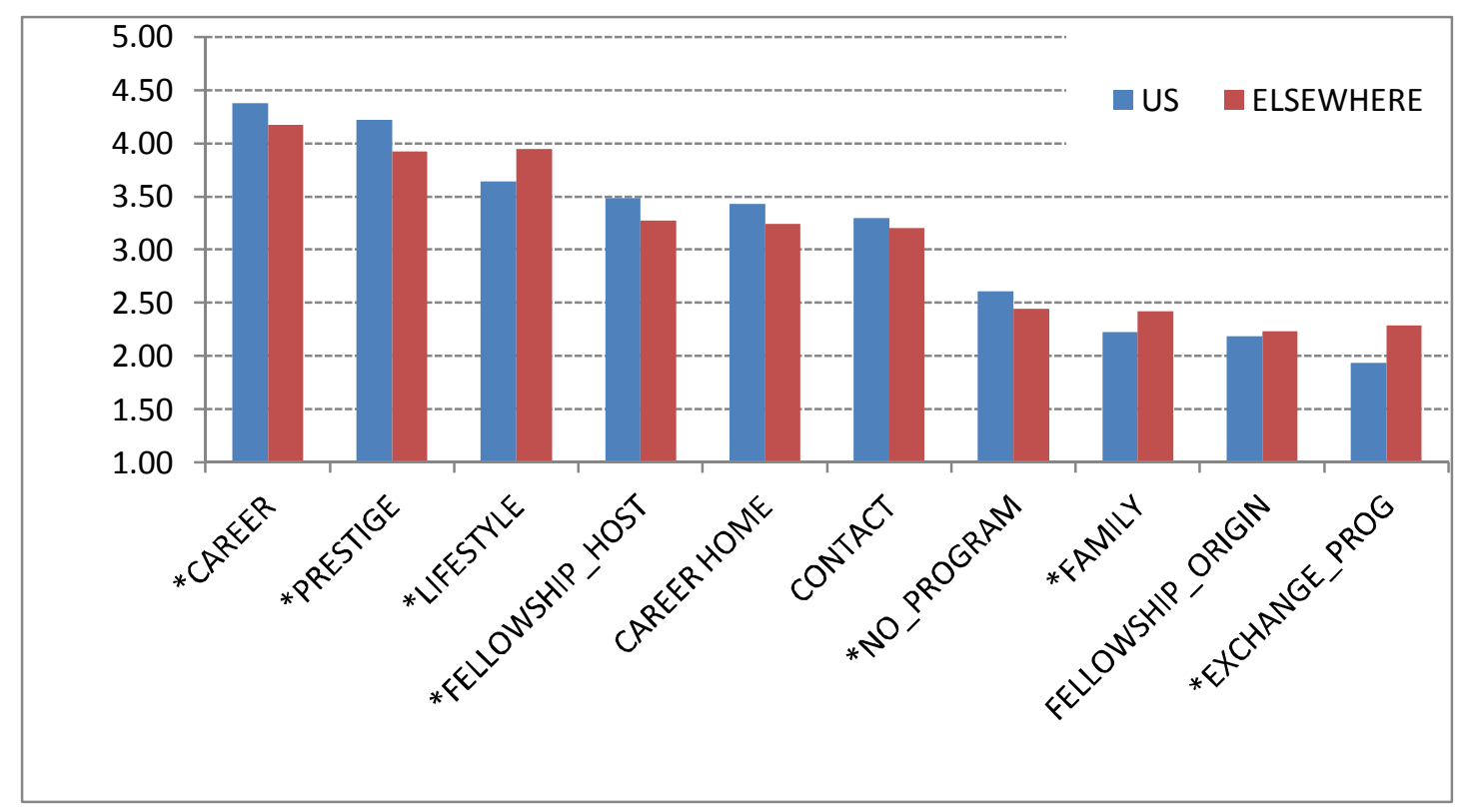

Table 6: Mean score, factors in decision to study abroad: Core country sample. T-test of specific destination vs. US

\begin{tabular}{|c|c|c|c|c|c|c|c|c|c|c|c|c|c|c|c|}
\hline & US & \multicolumn{2}{|c|}{ ELSEWHERE } & \multicolumn{2}{|l|}{ UK } & \multicolumn{2}{|c|}{ FRANCE } & \multicolumn{2}{|c|}{ CANADA } & \multicolumn{2}{|c|}{ AUSTRALIA } & \multicolumn{2}{|c|}{ SWITZERLAND } & \multicolumn{2}{|c|}{ GERMANY } \\
\hline PRESTIGE & 4.22 & 3.92 & *** & $4.11 *$ & * & 3.97 & $* * *$ & $3.61 *$ & $* * *$ & 3.32 & $* * *$ & 4.13 & & 4.06 & * \\
\hline CAREER & 4.38 & 4.18 & $* * *$ & 4.32 & & 4.06 & $* * *$ & $3.67 *$ & $* * *$ & 3.85 & $* * *$ & 4.18 & ** & 4.36 & \\
\hline CAREER HOME & 3.43 & 3.24 & $*$ & 3.51 & & 3.58 & & $2.69 *$ & $* * *$ & 2.81 & $* * *$ & 2.94 & $* * *$ & 3.36 & \\
\hline CONTACT & 3.30 & 3.20 & & 3.17 & & 3.44 & & 3.34 & & 3.08 & & 3.09 & & 3.17 & \\
\hline LIFESTYLE & 3.64 & 3.95 & $* * *$ & $4.02 *$ & $* * *$ & 4.18 & $* * *$ & 3.74 & & 3.83 & & 3.94 & ** & 3.78 & \\
\hline FAMILY & 2.22 & 2.42 & $* * *$ & 2.33 & & 2.24 & & $2.73 *$ & $* * *$ & 2.92 & $* * *$ & 2.44 & $*$ & 2.63 & $* * *$ \\
\hline EXCHANGE_PROG & 1.93 & 2.28 & $* * *$ & $2.25 *$ & $* * *$ & 2.97 & $* * *$ & 1.78 & & 1.81 & & 1.72 & & 2.55 & $* * *$ \\
\hline FELLOWSHIP_HOST & 3.48 & 3.27 & $* *$ & $3.13 *$ & $* * *$ & 3.02 & $* * *$ & 3.45 & & 3.64 & & 3.47 & & 3.27 & \\
\hline FELLOWSHIP_ORIGIN & 2.19 & 2.23 & & $2.43 *$ & $* *$ & 2.71 & $* * *$ & $1.80 *$ & $* * *$ & 1.96 & & 1.66 & $* * *$ & 2.21 & \\
\hline NO_PROGRAM & 2.61 & 2.44 & ** & 2.55 & & 2.48 & & $1.85 *$ & $* * *$ & 2.23 & $* * *$ & 2.34 & ** & 2.49 & \\
\hline
\end{tabular}


The GlobSci study also asked those who either did or were currently doing postdoctoral training abroad to assess on a five point scale the importance played by a larger set of factors than those scored by the PhD sample. Six variables specifically reflect conditions in the host country: faculty, funds, infrastructure, salary, fringe benefits and working conditions. The life quality variable reflects the match between preferences of the respondent and conditions in the host country. The 14 are defined in Table 7. Again we find considerable variation in the mean scores given individual factors. Career, faculty, prestige and expand network are all scored above "4." Three of these reflect policies and resources of the host country in relation to the research enterprise. Few jobs at home, working conditions, fringe benefits and family are all scored below the neutral "3."

Table 7 Description of factors in decision to study abroad for postdoctoral training

\begin{tabular}{|l|l|c|}
\hline & Variable name & Mean \\
\hline Career & Opportunity to improve my future career prospects & 4.4 \\
\hline Faculty & Outstanding faculty, colleagues or research team & 4.3 \\
\hline Prestige & Excellence/ prestige of the foreign institution in my area of research & 4.2 \\
\hline Expand network & Opportunity to extend my network of international relationships & 4.0 \\
\hline Infrastructure & Better research infrastructures and facilities & 3.9 \\
\hline Funds & Greater availability of research funds & 3.8 \\
\hline Lifestyle & Appeal of the life style or international experience & 3.8 \\
\hline Career_home & Opportunity to improve my future job prospects in the country where I lived when I was 18 & 3.7 \\
\hline Salary & Better wage / monetary compensation & 3.2 \\
\hline Life quality & Better quality of life & 3.2 \\
\hline Few jobs at home & Few or poor job opportunities in the country where I lived when I was 18 \\
\hline Working conds & Better working conditions(vacations, hours of work, ..) & 2.9 \\
\hline Fringe benefits & Better fringe benefits (parental leaves, pension, insurance, ..) & 2.7 \\
\hline Family & Family or personal reasons & 2.6 \\
\hline
\end{tabular}

Figure 5 compares the scores given the 14 factors by foreigners who did postdoctoral study in the US to the scores given the same factors by foreigners who did postdoctoral study in another core country for the Recent Cohort sample. Again, we find that the US and "elsewhere" means lie reasonably close together, suggesting that the same factors either do or do not matter for individuals who go abroad for postdoctoral training. Despite this, there are notable differences between those coming to the US vs. those going to another country. For example, the research environment, as measured by faculty, prestige, and infrastructure is scored significantly higher by those who did a postdoc in the US, as are career reasons, suggesting that science policy plays an important role in where individuals come to train. We also find that, although salary is not scored significantly differently, working conditions and fringe benefits are scored significantly higher for those doing postdocs outside the US than in the US. This is consistent with the (low) level of benefits and quality of working conditions available to many postdocs 
in the US, especially at the time many of the respondents did their postdoctoral study. As in the case of PhD recipients, lifestyle is scored significantly higher by those doing postdoctoral work outside the US than in the US. The life quality factor, which was only asked of those doing postdoctoral work abroad, is also scored significantly higher.

Figure 5 Importance of factors in decision to do a postdoc abroad: Recent cohort sample

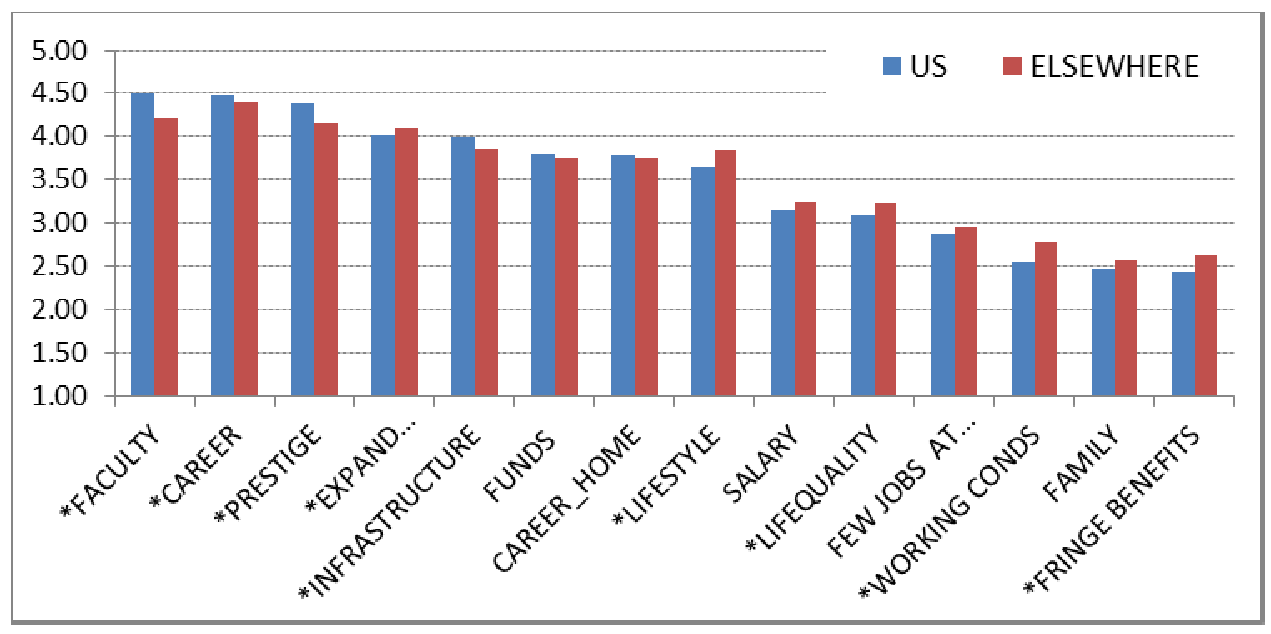

Table 8 compares mean scores on the factors given by postdocs coming to the US vs. those going to the six comparison countries. Again, we find that conditions affected by science policy play a role in bringing individuals to study in the US, although the findings are more nuanced. Uniformly respondents who do a postdoc in the US give significantly higher scores to faculty as a reason for coming than do those who did a postdoc in any of the other countries. This is not the case, however, for prestige, nor is it the case for infrastructure. These findings suggest that while the US research environment is scored as significantly more important by those doing postdoctoral study in the US vs. elsewhere, with the exception of faculty quality, the differences are not observed when we winnow the comparison down to this largely European set of countries. We also find that working conditions and fringe benefits play a larger role in the decision to train in Australia and Germany compared to in the US, although in neither case are the factors scored above neutral on the five point scale. Those who go to Switzerland for postdoctoral study appear to appreciate the relatively high salaries the Swiss offer. Working conditions, fringe benefits and the salary of postdocs are affected by science policy but have been largely neglected 
by policy makers in the US. Life quality draws postdocs to Switzerland, France, and Australia, relative to the United States; it discourages individuals from doing postdoctoral work in Great Britain.

Table 8: Mean score, factors in decision to do postdoctoral training abroad: Recent cohort sample. Ttest of specific destination vs. US

\begin{tabular}{|c|c|c|c|c|c|c|c|c|c|c|c|c|c|c|c|}
\hline \multirow[b]{2}{*}{ FACULTY } & \multirow{2}{*}{$\begin{array}{c}\text { US } \\
4.49\end{array}$} & \multicolumn{2}{|c|}{ ELSEWHERE } & \multicolumn{2}{|c|}{ UK } & \multicolumn{2}{|c|}{ FRANCE } & \multicolumn{2}{|c|}{ CANADA } & \multicolumn{2}{|c|}{ AUSTRALIA } & \multicolumn{2}{|c|}{ SWITZERLAND } & \multicolumn{2}{|c|}{ GERMANY } \\
\hline & & 4.20 & $* * *$ & 4.32 & $* * *$ & 4.14 & $* * *$ & 4.18 & $* * *$ & 4.06 & $* * *$ & 4.30 & $* *$ & 4.35 & $* *$ \\
\hline CAREER & 4.49 & 4.39 & $* *$ & 4.52 & & 4.37 & & 4.29 & $* *$ & 4.32 & & 4.39 & & 4.46 & \\
\hline PRESTIGE & 4.38 & 4.16 & $* * *$ & 4.28 & & 4.25 & & 4.11 & $* * *$ & 3.94 & $* * *$ & 4.25 & & 4.29 & \\
\hline $\begin{array}{l}\text { EXPAND } \\
\text { NETWORK }\end{array}$ & 4.01 & 4.09 & $* *$ & 4.16 & $* *$ & 4.19 & $*$ & 4.06 & & 4.12 & & 3.97 & & 4.13 & \\
\hline INFRASTRUCTURE & 4.00 & 3.87 & $* * *$ & 3.91 & & 3.88 & & 3.90 & & 3.67 & $* * *$ & 4.11 & & 4.12 & \\
\hline FUNDS & 3.81 & 3.75 & & 3.74 & & 3.65 & $*$ & 3.94 & & 3.62 & & 3.97 & & 3.93 & $*$ \\
\hline CAREER_HOME & 3.78 & 3.75 & & 3.85 & & 3.79 & & 3.61 & & 3.55 & & 3.46 & $* * *$ & 3.91 & \\
\hline LIFESTYLE & 3.65 & 3.83 & $* * *$ & 3.77 & & 3.65 & & 3.70 & & 4.29 & $* * *$ & 3.86 & $*$ & 3.83 & $* *$ \\
\hline SALARY & 3.16 & 3.24 & & 3.18 & & 3.02 & & 3.21 & & 3.36 & & 3.63 & $* * *$ & 3.33 & $*$ \\
\hline LIFEQUALITY & 3.09 & 3.23 & $* *$ & 2.74 & $* * *$ & 3.32 & $* *$ & 3.35 & $* *$ & 3.83 & $* * *$ & 3.43 & $* *$ & 3.24 & $*$ \\
\hline $\begin{array}{l}\text { FEW JOBS AT } \\
\text { HOME }\end{array}$ & 2.87 & 2.96 & $*$ & 3.19 & $* * *$ & 3.02 & & 2.84 & & 3.00 & & 2.97 & & 2.91 & \\
\hline WORKING CONDS & 2.54 & 2.78 & $* * *$ & 2.54 & & 2.73 & & 2.77 & $*$ & 3.00 & $* * *$ & 2.75 & & 2.74 & $* *$ \\
\hline FAMILY & 2.46 & 2.56 & $*$ & 2.24 & $* *$ & 2.40 & & 2.77 & $* *$ & 2.74 & $*$ & 2.62 & & 2.63 & $* *$ \\
\hline FRINGE BENEFITS & 2.43 & 2.63 & $* * *$ & 2.33 & * & 2.62 & & 2.63 & & 2.82 & $* * *$ & 2.62 & * & 2.81 & $* * *$ \\
\hline
\end{tabular}

Figure 6 compares the scores given to the 14 factors for foreigners doing postdoctoral study in the US to the scores given the same factors by foreigners who postdoc elsewhere for the Core Country sample. For this sample, which draws individuals from a more restricted set of countries of origin, but includes individuals who received their doctoral training before and after 2000, we find four of the factors to receive a score below that of a "neutral" "3." They are few jobs at home, working conditions, family and fringe benefits. Two others hover close to a neutral "3." The other ten are scored above 3.5.

Again we find some variation among the scores given by foreigners studying in the US vs. elsewhere, although overall the means lie closely together. The differences that do exist suggest that science policy plays a role in bringing individuals to the US for postdoctoral training. To wit, the research environment, as measured by faculty, prestige, infrastructure and funds, is scored significantly higher by those doing a postdoc in the US than elsewhere. Career outcomes-both at home and in general-- are scored significantly higher by those doing a postdoc in US vs. elsewhere. Working conditions and fringe benefits, however, which have been largely neglected by policy makers in the US, are scored 
significantly lower by those doing postdoc work in the US than by those doing a postdoc outside the US. Life quality and life style once again are scored higher by those going elsewhere.

Figure 6 Importance of factors in decision to do a postdoc abroad: Core country sample

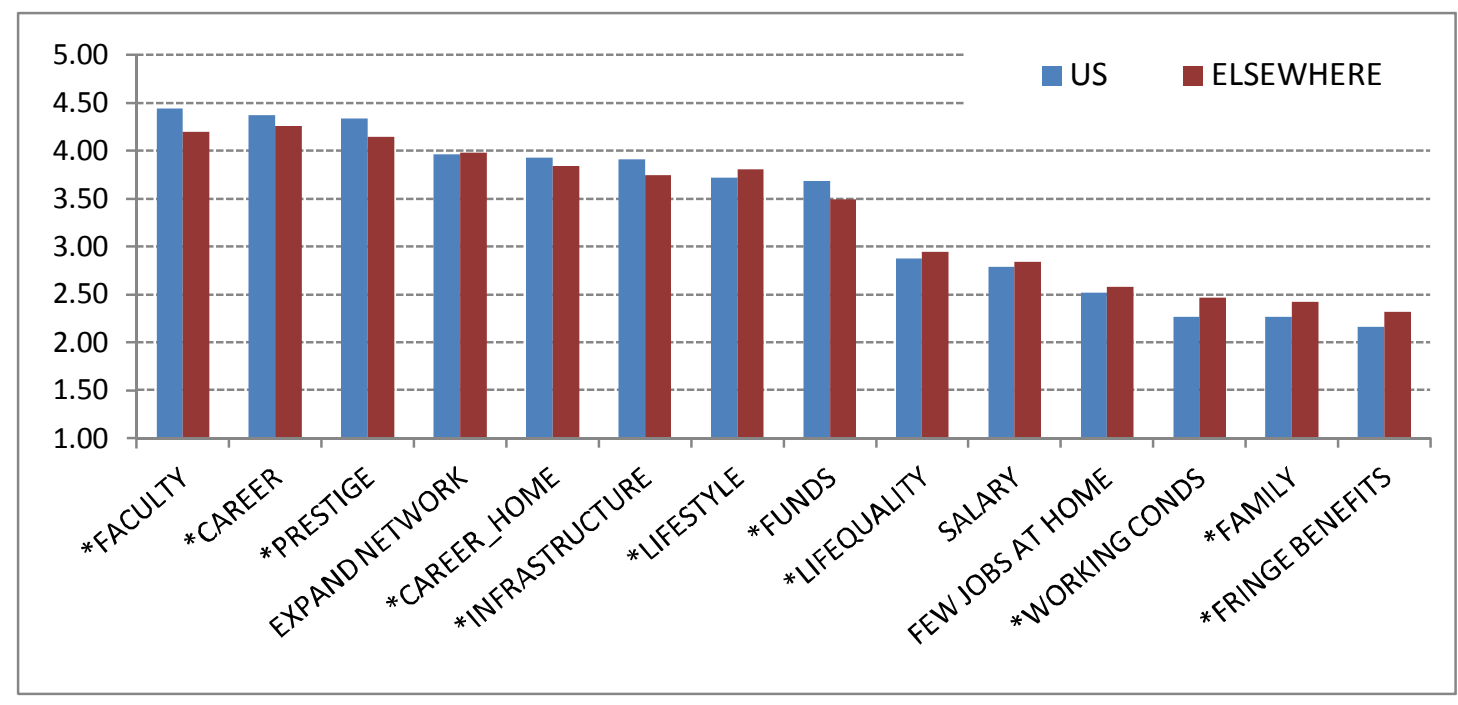

Table 9: Mean score, factors in decision to do a postdoctoral training abroad: Core country sample. Ttest of specific destination vs. US

\begin{tabular}{|c|c|c|c|c|c|c|c|c|c|c|c|c|c|c|c|}
\hline \multirow[b]{2}{*}{ FACULTY } & \multirow{2}{*}{$\frac{\text { US }}{4.44}$} & \multicolumn{2}{|c|}{ ELSEWHERE } & \multicolumn{2}{|c|}{ UK } & \multicolumn{2}{|c|}{ FRANCE } & \multicolumn{2}{|c|}{ CANADA } & \multicolumn{2}{|c|}{ AUSTRALIA } & \multicolumn{2}{|c|}{ SWITZERLAND } & \multicolumn{2}{|c|}{ GERMANY } \\
\hline & & 4.20 & $* * *$ & 4.31 & $* * *$ & 4.14 & $* * *$ & 4.16 & $* * *$ & 4.03 & $* * *$ & 4.41 & & 4.37 & $*$ \\
\hline CAREER & 4.37 & 4.26 & $* * *$ & 4.35 & & 4.24 & $* * *$ & 4.25 & $* * *$ & 4.11 & $* * *$ & 4.30 & $*$ & 4.25 & $* * *$ \\
\hline PRESTIGE & 4.33 & 4.15 & $* * *$ & 4.30 & & 4.11 & $* * *$ & 3.93 & $* * *$ & 3.83 & $* * *$ & 4.34 & & 4.34 & \\
\hline $\begin{array}{l}\text { EXPAND } \\
\text { NETWORK }\end{array}$ & 3.96 & 3.98 & & 4.06 & $* *$ & 3.99 & & 3.83 & $* *$ & 3.98 & & 3.93 & & 4.04 & $*$ \\
\hline CAREER_HOME & 3.93 & 3.85 & $* * *$ & 3.94 & & 3.80 & $* *$ & 3.59 & $* * *$ & 3.47 & $* * *$ & 3.58 & $* * *$ & 3.89 & \\
\hline INFRASTRUCTURE & 3.91 & 3.75 & $* * *$ & 3.77 & $* * *$ & 3.76 & $* * *$ & 3.67 & $* * *$ & 3.34 & $* * *$ & 4.06 & $* *$ & 3.95 & \\
\hline LIFESTYLE & 3.72 & 3.81 & $* * *$ & 3.81 & $* *$ & 3.72 & & 3.79 & & 4.29 & $* * *$ & 3.82 & & 3.81 & \\
\hline FUNDS & 3.69 & 3.49 & $* * *$ & 3.38 & $* * *$ & 3.48 & $* * *$ & 3.54 & $* *$ & 3.22 & $* * *$ & 3.83 & $*$ & 3.66 & \\
\hline LIFEQUALITY & 2.88 & 2.94 & $* * *$ & 2.61 & $* * *$ & 3.01 & $* * *$ & 3.10 & $* * *$ & 3.67 & $* * *$ & 3.15 & $* * *$ & 2.91 & \\
\hline SALARY & 2.79 & 2.84 & & 2.70 & $*$ & 2.81 & & 2.70 & & 2.97 & & 3.25 & $* * *$ & 2.96 & $* * *$ \\
\hline $\begin{array}{l}\text { FEW JOBS AT } \\
\text { HOME }\end{array}$ & 2.52 & 2.58 & & 2.52 & & 2.68 & $*$ & 2.64 & & 2.84 & $* *$ & 2.63 & & 2.46 & \\
\hline WORKING CONDS & 2.27 & 2.47 & $* * *$ & 2.25 & & 2.43 & $* *$ & 2.38 & $* *$ & 2.66 & $* * *$ & 2.51 & $* * *$ & 2.54 & $* * *$ \\
\hline FAMILY & 2.27 & 2.42 & $* * *$ & 2.21 & & 2.39 & $* *$ & 2.60 & $* * *$ & 2.66 & $* * *$ & 2.42 & $* *$ & 2.42 & $* * *$ \\
\hline FRINGE BENEFITS & 2.16 & 2.32 & $* * *$ & 2.09 & $* *$ & 2.37 & $* * *$ & 2.29 & $* *$ & 2.61 & $* * *$ & 2.37 & $* * *$ & 2.40 & $* * *$ \\
\hline
\end{tabular}


Table 9 compares mean scores for the Core sample of postdocs between the US and the same six countries. There are few surprises. Measures of the research environment and career outcomes, both affected by science policy, are generally scored higher by those training in the US. Working conditions and fringe benefits, which are also affected by science policy, are scored significantly lower. Quality of life pulls trainees to most other countries rather than to the US.

\subsection{Trends over time}

Tables 10 and 11 present data on the percent of mobile PhD recipients who have received their PhD in the US vs. another country as well as the percent of mobile postdoctoral scholars for the Core Country sample and the Recent Cohort sample. Consistent with the increase in the number of foreign students studying outside the US, and the effort that many countries are making to attract foreign students, we find the trend for doctoral study in the US declining--both for the Core Country sample, which tracks recipients before and after 2000, and the Recent Cohort sample. We find a similar decline for those coming to the US for postdoctoral study, especially for the Core Country sample. When we model coming to the US vs. going to one of the six countries discussed previously, we find that three countries have been nibbling at the US's position: Australia, Switzerland and Germany (Stephan, Franzoni, \& Scellato, 2013). When it comes to postdoctoral training, our modeling suggests that all of the six countries, with the exception of Canada, have been nibbling at the US postdoc share.

Table 10 Mobile PhDs and Postdocs. Percent going to US vs. all other destinations ${ }^{36}$. Core country sample.

\begin{tabular}{|l|c|c|}
\hline Years & $\begin{array}{c}\text { Percent US vs. all other destinations for } \\
\text { PhDs }\end{array}$ & $\begin{array}{c}\text { Percent US vs. all other destinations for } \\
\text { Postdocs }\end{array}$ \\
\hline Before 1980 & 46.72 & 47.99 \\
\hline $1980-1989$ & 37.22 & 48.66 \\
\hline $1990-1999$ & 35.30 & 40.71 \\
\hline $2000-2011$ & 26.65 & 34.99 \\
\hline
\end{tabular}

\footnotetext{
${ }^{36}$ All data weighted by country specific response rates.
} 
Table 11 Mobile PhDs and Postdocs. Percent going to US vs. all other destinations ${ }^{37}$. Recent cohort sample.

\begin{tabular}{|l|c|c|}
\hline Years & $\begin{array}{c}\text { Percent US vs. all other destinations for } \\
\text { PhDs }\end{array}$ & $\begin{array}{c}\text { Percent US vs. all other destinations for } \\
\text { Postdocs }\end{array}$ \\
\hline $2000-2003$ & 40.12 & 41.04 \\
\hline $2004-2006$ & 30.58 & 27.22 \\
\hline $2007-2009$ & 32.34 & 34.75 \\
\hline after 2009 & 30.95 & 34.70 \\
\hline
\end{tabular}

\section{Discussion and Conclusion}

The GlobSci survey provides a snapshot, taken in 2011, of foreign-born scientists working or training in sixteen core countries. The data provide a rare look, given the lack of comparable country-level data, at how countries compare in terms of the proclivity to train the foreign born in science and the proclivity of residents to go abroad for training. It also provides insight into factors associated with PhD and postdoctoral scholars' choice of one country over another for study abroad. We cannot, however, establish causality between these various factors and the choices trainees make given the snapshot nature of our data. In this regard, we do not know the degree to which respondents value expost characteristics of the institution and country where they trained more than they did exante. Nor do we have measures of the choice set that scientists faced at the time they made their decision of where to study.

Major findings from our analysis of the GlobSci data include wide variation by country in the proclivity of foreign students to train in country. In this respect, and measured in terms of percent of those in country who are foreign, the US leads in being a destination country for PhD training, but Switzerland and the UK are close on its heels and Switzerland leads the pack when it comes to postdoctoral training. Countries at the other extreme are India, Italy and Brazil with less than 4 percent of the doctoral or postdoctoral-trained work force being foreign born. Countries also vary considerably in the proclivity of residents to study abroad. Indians have the highest propensity to leave for PhD study; the Swiss have the highest for postdoctoral training, followed closely by the French. The most insular, when it comes to

\footnotetext{
${ }^{37}$ All data weighted by country specific response rates.
} 
leaving either for doctoral or postdoctoral training, are US residents. For doctoral training, the distinction is shared with residents of Japan.

Our survey finds that the probability of training in the US vs. a third country has decreased over time. For example, while close to half of all mobile PhD recipients from core countries came to the US vs. a third country before 1980, in the last decade, the percent has been cut almost in half. The percent of mobile postdoctoral scholars coming to the US has also decreased, although not as dramatically. Countries that appear to have attracted PhD students away from the US are Australia, Germany, and Switzerland. At the postdoctoral level, Canada is the only one of the six countries we examine that has not nibbled at the US share.

Our research suggests that science policy plays an important role in attracting the foreign born to study in a country. The public policy case rests on several findings.

- At a highly aggregate level, the percent of the doctoral workforce in a country that is foreign and trained in country is positively and significantly correlated with the H-Index and the QS ranking of university quality in the country, as is the percent of the workforce with postdoctoral training. Both the $\mathrm{H}$-Index and the QS measure reflect investments a country has made in research and higher education. We also find a strong negative correlation between the score mobile scientists give to the unavailability of programs in their home country as a reason for studying abroad and the educational and research environment in the country as measured by the $\mathrm{H}$ Index and the percent of GDP spent on higher education, research and development (HERD).

- Visa policy clearly matters. If there were a shadow of a doubt it is dispelled by looking at what happened to the number of PhDs awarded to foreign citizens after the visa restrictions of post 9/11 were enacted in the US.

- Respondents score measures of the quality of the research environment in the country of training as highly important in their decision to study abroad. Prestige is ranked at or near the top across all factors for PhD study and for postdoctoral study. The faculty quality variable, which was only scored by postdoctoral recipients, ranks at the very top. Both faculty quality and prestige depend in part on the amount of resources a country invests in research and training.

- Respondents score the availability of financial assistance from the host country as playing an important role in their decision to study abroad. Again, the availability of funding is highly dependent on policy. 
- Respondents score career opportunities outside their home country as extremely important (if not the most important) in their decision to study abroad, suggesting that they view foreign training as an entrée to a career in a different country. Clearly these career opportunities depend upon the visa policies of host countries and labor market conditions in host countriesboth variables that are affected by policy.

Our research suggests that the US is a magnet for foreign students and postdocs precisely because the US has excelled in creating a strong educational and research environment. Moreover, our work suggests that students who come to the US appreciate these strengths, scoring factors that are proxies for the research environment higher than students who go to most other countries for training.

Our findings are fairly similar for PhD students and postdoctoral scholars who come to the US. A strong educational and research environment is scored highly as a reason for taking a postdoc and these factors are more highly scored by those coming to the US than going elsewhere. However, foreign postdocs coming to the US score the availability of fringe benefits and working conditions lower than those going to other countries. The finding should not come as a surprise given the relatively modest fringe benefits and the less than ideal working conditions available for many postdocs in the US and suggests that in this regard the US is not competitive with other countries.

Our research suggests that those who go elsewhere than the US for study weigh life style and life quality as being more important in their decision to go abroad than do those coming to the US. While public policy clearly affects life style and life quality, they are largely outside the domain of science policy. They also suggest that the presence of exchange programs plays a role in leading individuals to go to a third country rather than to the US for doctoral training.

What do our results suggest concerning the ability of the US to continue to attract the foreign born for PhD study and postdoctoral training?

- The US's ability to continue to draw individuals to come for training depends upon its ability to remain a top producer of research. At a minimum, this requires directing resources to university research. In recent years the flow of federal resources to universities for research and development has been virtually flat in real terms except for the two years that the American Recovery and Reinvestment Act (ARRA) funding was available. Federal budget issues and the 
politics of Congress mean that resources could remain reasonably stagnant in the foreseeable future.

- Career prospects play a role in attracting individuals for training to the US. In recent years these prospects have not been stellar. Career prospects, however, are relative; compared to many European countries the US has been doing reasonably well when it comes to employment opportunities for newly-trained scientists.

- Having top-rated universities clearly contributes to the US's ability to attract foreign students and postdocs. Many of these institutions, however, are public and have traditionally depended upon state legislatures for a portion of their support. In recent years they have found their funding increasingly threatened and increasingly have had to look elsewhere for sources of support. Just how long they can continue finding sufficient resources to remain competitive is an open question.

- Visa policies both in the United States and elsewhere play a role in where the foreign born go for study and postdoctoral training and whether they stay after the training. Policies implemented in the wake of $9 / 11$ affected flows to the US and policies of other countries have affected flows. Visa reform in the US, a topic of current discussion, has the potential of affecting future flows of trainees to the US.

In the long run the real challenge to the United States' training hegemony is likely to come from Chinanot from Europe, Australia or Canada-in terms of China retaining native students for PhD study and postdoctoral training as well as attracting foreign students to China for training. In the short run, however, the tremendous growth in the number of undergraduates in training in China should increase the demand for those coming abroad for training. The Chinese, after all, have had a strong tradition of coming to the Untied States, a tradition that is unlikely to change in the near future.

\section{Bibliography}

Alden, E. (2008). The Closing of the American Border: Terrorism, Immigration, and Security since 9/11. New York: Harper Perennial.

Aslanbeogio, N., \& Monticinos, V. (1998). Foreign Students in US Doctoral Programs. Journal of Economic Perspectives, 17(3), 171-182. 
Beine, M., Noel, R., \& Ragot, L. (2012). The Determinants of International Mobility of Students. CESifo.

Black, G., \& Stephan, P. (2010). "The Economics of University Lab Science and the Role of Foreign Graduate Students and Postdoctoral Scholars". In C. Clotfelter, American Universities in a Global Market (pp. 129-162). Chicago: University of Chicago Press.

Blume-Kohout, M., \& Clark, J. W. (2013, December 23). Are Graduate Students Rational? Evidence from the Market for Biomedical Scientists. PLOS: One.

Bound, J., Turner, S., \& Walsh, P. (2009). Internationalization of U.S. Doctorate Education. In R. B. Goroff, Science and Engineering Careers in the United States (pp. 59-98). Chicago: University of Chicago PRess.

Cantwell, B., \& Taylor, B. H.-5. (2013). , Internationalization of the postdoctorate in the United States: analyzing the demand for international postdoc labor. Higher Education, 66, 551-567.

Chaloff, J., \& Lemaitre, G. (2009). Managing Highly-Skilled Labour Immigration: A Comparative Analysis of Migration Policies and Challenges in OECD Cuntries. Paris, France.: OECD Social, Employment and Migration Working Paper No. 79. .

EU Commission Report. (2012). Statistics: Marie Curie Action Research Fellowships: 27 Country Fact Sheets.

Finn, M. G. (2012). Stay Rates of Foreign Doctorate Recipients from US Universities, 2009. Oak Ridge Institute for Science and Education.

Franzoni, C., Scellato, G., \& Stephan, P. (2012). Foreign-born Scientists: Mobility Patterns for 16 Countries. Nature Biotechnology, 30, 1250-1253.

Franzoni, C., Scellato, G., \& Stephan, P. (2014). Superior Performance of Migrant Scientists. Economics Letters, 12, 89-93.

Freeman, R. B. (2010). What Does Global Expansion of Higher Education Mean for the United States? In C. Clotfelter, American Universities in a Global Market. Cambridge, MA: MIT Press.

Garrison, H., Stith, A., \& Gerbi, S. (2005). Foreign Postdocs: The Changing Face of Biomedical Science in the United States. The FACEB Journal, Life Sciences, 19, 1938-1942.

Gaule, P., \& Piacentini, M. (2013). Chinese Graduate Students and US Scientific Productivity. Review of Economics and Statistics, 95, 298-701.

Grogger, J., \& Hanson, G. H. (2013). Attracting Talent: Location Choices of Foreign-Born PhDs in the US. NBER Working Paper 18780.

Hawthorne, L. (2009). The Growing Global Demand for Students as Skilled Migrants. University of Melbourne, Migration Policy Institute. 
IISER. (2007). Intra-EU mobility of Researchers. Institute for Prospective Technological Studies jointly with European Commission, Joint Research Center.

Kahn, S., \& MacGarvie, M. (2012). The Effects of the Foreign Fulbright Program on Knowledge Creation. In NBER 50th Anniversary Conference Volume on the Rate an on Knowledge Creation d Direction of Inventive Activity (pp. 161-197). Chicago, IL: University of Chicago Press.

Levin, S., \& Stephan, P. (1999). Are the Foreign Born a Source of Strength for US Science? Science, 295, 1213-1214.

Lowell, L. (2000). H-1B Temporary Workers: Estimating the Population. Working Paper 12.

Marginson, S., \& van der Wende, M. (2007). Globilisation and Higher Education. Paris: OECD.

Mazzarol, T., \& Soutar, G. N. (2002). "“Push-pull” factorsinfluencing international student destination choice. International Journal of Educational Management, 16, 82-90.

Mervis, J. (2008). Top PhD Feeder Schools Are Now Chinese. Science, 321, 185.

Mowery, D. (1999). America's Industrial Resurgence: How Strong, How Durable? Issuses in Science and Technology, 15(3), 41-48.

Musselin, C. (2004). Towards a European Academic Labour Market? Some Lessons Drawn from Empirical Studies on Academic Mobility/. Higher Education, 48, 55-78.

National Postdoctoral Association. (2012). Institutional Survey on Postdoctoral Compensation, Benefits and Professional Development Opportunities.

National Science Board. (2008). Science and Engineering Indicators 2008. Arlington, VA: National Science Foundation.

National Science Board. (2012). Science and Engineering Indicators 2012. Arlington, VA.: National Science Foundation.

National Science Foundation. (2013). Doctorate Recipients from US Universities: 2012. Arlington, VA.

New York Times editorial. (2013, December 7). Who Says Math Has to Be Boring? New York Times.

OECD. (2009). Education at a Glace 2009: OECD Indicators. OECD.

Perkins, R., \& Neumayer, E. (2011). Geographies of Educational Mobilities: Exploring Unevenness, Differences and Changes in International Student Flows. Working Paper, London School of Economics \& Political Science.

Regets, M. (2005). Foreign Students in the United States.

Sauermann, H., \& Roach, M. (2010). A Taste for Science? PhD Scientists' Academic Orientation and SelfSelection in Research Careers in Industry. Research Policy, 39(3), 422-434. 
Sauermann, H., \& Roach, M. (2013). Increasing Web Survey Response Rates in Innovation Research: An Experimental Study of Static and Dynamic Contact Design Features. Research Policy, 273-296.

Scellato, G., Franzoni, C., \& Stephan, P. (2014). Mobile Scientists and International Networks.

Stephan, P. (2007). Wrapping It Up in a Person: The Mobility Patterns of New PhDs. In J. \&. Lerner, Innovation Policy and the Economy, Volume 7. Cambridge, MA: MIT Press.

Stephan, P. (2010). The I's Have It: Immigration and Innovation, the Perspective from Academe. In J. Lerner, \& S. Stern, Innovation Policy and the Economy, Vol. 10 (pp. 83-127). Cambridge, MA: MIT Press.

Stephan, P. (2012). How Economics Shapes Science. Boston: Harvard University Press.

Stephan, P., \& Ma, J. (2005, May). The Increased Frequency and Duration of the Postdoctorate Career Stage. The American Economic Review, 95, 71-75.

Stephan, P., Franzoni, C., \& Scellato, G. (2013). Choice of Country by the Foreign Born for PhD and Postdoctoral Study: A Sixteen-country Perspective. Cambridge, MA: NBER Working Paper 18809.

Teitelbaum, M. (2014). Falling Behind: Is the U.S. Losing a Global Race for Talent (working title). Princeton, NJ: Princeton University Press.

Tysome, T. (2006, August 11). Overseas cash injections rises. Times Higher Education Supplement.

Van Bouwel, L., \& Veugelers, R. (2012). An 'Elite Brain Drain': Are foreign top PhDs more likely to stay in the US? Open access publications from Katholieke Universiteit Leuven.

van der Wende, M. (2013). International Academic Mobility (in Europe): Towards a Concentration of the Minds? Presented at "Migration and Mobility in Science: Impacts on Cultures and the Profession".

Verbik, L., \& Lasanowski, V. (2007). International Student Mobility: Patterns and Trends. London: Research Report, The Observatory on Borderless Higher Education.

Walsh, J. P., Cho, C., \& Cohen, W. (2005). View from the Bench: Patents and Material Transfers. Science, 2002-2003.

\section{Appendix}

We examine the degree to which the GlobSci data are representative of degree patterns in the US by comparing the percent of degrees awarded in the US since 1999 to specific nationalities as reported in the GlobSci data to data collected by the Survey of Earned Doctorates (SED) on the population of PhD recipients in the US. The comparison is limited by the fact that, short of getting a license to use the SED, data on country of origin by field of study are not available. The SED does report the percent of degrees 
awarded to US citizens as well as the number of degrees awarded to individuals coming from the top ten foreign countries. The data for the latter are only available for the broad field of "science and engineering" which includes the fields of engineering, social sciences and psychology.

The major issue that arises in making comparisons is that engineering is heavily populated by foreign students; the social sciences are moderately populated by the foreign born; and psychology has a minimal number of foreign students. In 2006, 50.9 percent of degrees in these three fields were awarded to US citizens; 49.1 percent were awarded to permanent residents, temporary residents and those not declaring citizenship. The 50.9 percent is considerably lower than the underlying benchmark of 56.5 percent found in the SED data, indicating that the SED benchmark we are forced to use, which includes these three fields, understates the percent who are US citizens and overstates the percent who are foreign in the fields that we study.

Comparisons are presented in Table A.1.

Table A.1 Comparison of GlobSci Data with SED data, post 1999 PhD recipients in US

\begin{tabular}{|l|c|c|}
\hline Country of origin & Percent reported in GlobSci, after 1999 & $\begin{array}{c}\text { Percent reported in SED for all PhDs in } \\
\text { science and engineering, 2001-2009* }\end{array}$ \\
\hline USA & 63.7 & 55.4 (56.5) \\
\hline China & 9.4 & 4.3 \\
\hline India & 4.3 & 1.1 \\
\hline Canada & 2.1 & 3.4 \\
\hline Korea & 2.1 & 0.5 \\
\hline Germany & 1.0 & 1.5 \\
\hline Russia & 1.0 & \\
\hline Taiwan & 1.0 & \\
\hline Brazil & 0.9 & 0.6 \\
\hline UK & 0.9 & \\
\hline Japan & 0.9 & \\
\hline Italy & 0.8 & \\
\hline Australia & 0.6 & \\
\hline Spain & 0.6 & \\
\hline Argentina & 0.5 & \\
\hline Switzerland & 0.5 & \\
\hline Mexico & 0.5 & \\
\hline Turkey & 0.5 & \\
\hline NData & 0.6 & \\
\hline
\end{tabular}

*Data reported for countries with 7 or more US PhD recipients in the GlobSci data. NSF reports data for the top ten countries represented among US-PhD recipients. There were 7 or more US PhD recipients for nine of these in the GlobSci data post 1999. For US, percent reported is for citizens and permanent residents; percent reported in italics is for citizens and excludes permanent residents. 